American Journal of Biochemistry and Biotechnology 6 (3): 213-230, 2010

ISSN 1553-3468

(C) 2010 Science Publications

\title{
Effects of Cooling and Supplemental Bovine Somatotropin on Milk Production relating to Body Glucose Metabolism and Utilization of Glucose by the Mammary Gland in Crossbred Holstein Cattle
}

\author{
${ }^{1}$ Siravit Sitprija, ${ }^{2}$ Somchai Chanpongsang and ${ }^{1}$ Narongsak Chaiyabutr \\ ${ }^{1}$ Department of Veterinary Physiology, \\ ${ }^{2}$ Department of Animal Husbandry, \\ Faculty of Veterinary Science, Chulalongkorn University, Bangkok 10330, Thailand
}

\begin{abstract}
Problem statement: The low milk yield and shorter persistency of lactation of dairy cattle is the major problem for the dairy practices in the tropics. High environmental temperatures and rapid decline of plasma growth hormone level can influence milk production. Regulation of the milk yield of animals is mainly based on the mechanisms governing the quantity of glucose extracted by the mammary gland for lactose biosynthetic pathways. The mechanism(s) underlying the effects of cooling and supplemental bovine somatotropin on milk production relating to body glucose metabolism and intracellular metabolism of glucose in the mammary gland of crossbred Holstein cattle in the tropics have not been investigated to date. Approach: Ten crossbred 87.5\% Holstein cows were divided into two groups of five animals each. Animals were housed in Normal Shade barn (NS) as non-cooled cows and cows in the second group were housed in barn which was equipped with a two Misty-Fan cooling system (MF) as cooled cows. Supplementation of recombinant bovine Somatotropin (rbST) (POSILAC, $500 \mathrm{mg}$ per cow) were performed in both groups to study body glucose metabolism and the utilization of glucose in the mammary gland using a continuous infusion of $\left[3-{ }^{3} \mathrm{H}\right]$ glucose and [U${ }_{14} \mathrm{C}$ ] glucose as markers in early, mid and late stages of lactation. Results: Milk yield significantly increased in both groups during supplemental rbST with a high level of mammary blood flow. Body glucose turnover rates were not significant different between cooled and non-cooled cows whether supplemental rbST or not. The glucose taken up by the mammary gland of both non-cooled and cooled cows increased flux through the lactose synthesis and the pentose cycle pathway with significant increases in NADPH formation for fatty acid synthesis during rbST supplementation. The utilization of glucose carbon incorporation into milk appeared to increase in milk lactose and milk triacylglycerol but not for milk citrate during supplemental rbST in both non-cooled and cooled cows in early and mid lactation. Conclusion: The present study demonstrated that local changes for biosynthetic capacity within the mammary gland would be a factor in identification of the utilization of substrates in the rate of decline in milk yield. The proportion of glucose was metabolized less for lactose synthesis, but metabolized more via the Embden-Meyerhof pathway and the tricarboxylic acid cycle as lactation advanced to late lactation in both cooled and non-cooled cows whether supplemental rbST or not.
\end{abstract}

Key words: rbST, glucose metabolism, mammary gland, crossbred Holstein cow

\section{INTRODUCTION}

The low milk yield and short lactation period of either pure exotic or crossbred dairy cattle is still the major problem for the dairy practices in the tropics. The mechanisms that limit the rate of milk yield and shorter lactation persistency as lactation advances in crossbred dairy cattle in tropics are unclear. It is not only animal genetics that are considered but other factors, for example, high environmental temperatures and hormonal factors can influence milk production (Collier et al., 1982). The study in $87.5 \%$ crossbred Holstein cattle (HF) showed rapid decline in the concentration of plasma bovine Somatotropin (bST), which would accompany with a reduction in both mammary blood flow and milk yield as lactation progressed to mid and late lactation (Chaiyabutr et al., 2000a). Many studies demonstrated the efficacy of bST for improvement in milk yield (Breier et al., 1991; Burton et al., 1994). Long term exogenous recombinant

Corresponding Author: Narongsak Chaiyabutr, Department of Veterinary Physiology, Faculty of Veterinary Science, Chulalongkorn University, Bangkok 10330, Thailand 
bovine Somatotropin (rbST) in $87.5 \%$ HF cow increased in milk yield which accompanied with an increase in the rate of mammary blood flow, but the stimulant effect for milk yield was less in late lactation despite a high level of mammary blood flow (Chaiyabutr et al., 2007). It is not known which factors are the cause and which factors are the effects for such reduction.

It is well recognized that prolonged high ambient temperatures can affect either directly or indirectly to the ability of dairy cow to synthesize milk production. Environmental modifications such as fans and sprinklers (Fike et al., 2002) or evaporative cooling system (Chan et al., 1997; Chaiyabutr et al., 2008a) can be used to alleviate of severe heat stress and increase in milk production in dairy cattle. In addition to environmental modifications, other technologies can increase milk production in dairy cattle, for example, by supplementation of dietary methionine (Yang et al., 2010), or the application of exogenous bovine somatotropin (West et al., 1991; West, 1994). Somatotropin is known to play a role in responsible for galactopoietic and contributing to homeostasis and homeorhesis in ruminants (Bauman and Currie, 1980). However, few data are available on the combined effects of high environmental temperatures and bST administration on mechanisms of milk secretion.

Glucose is known to be the principal precursor of lactose synthesis. Lactose is the major osmotic factor of milk synthesis and is required in proportion to the amount of milk produced (Linzell and Peaker, 1971). The regulation of the milk yield is mainly based on the quantity of glucose extracted by the mammary gland and converted into lactose. The rapid decline in lactose biosynthetic pathways has been shown to account for a short persistency of lactation as lactation advanced to mid and late lactation in $87.5 \% \mathrm{HF}$ cows in either without rbST administration (Chaiyabutr et al., 2000b) or long-term administration of rbST (Chaiyabutr et al., 2008b). During long-term administration of rbST, the utilization of glucose in the mammary gland was metabolized less for lactose synthesis and the pentose phosphate pathway but metabolized more via the Embden-Meyerhof pathway as lactation advances (Chaiyabutr et al., 2008b). Cows treated with bST does not only increase efficiencies of milk yields, but also increase heat production, which was probably due to increased metabolic activity associated with higher milk yield (West, 1994). The high heat production in rbST treated-cows with high ambient temperatures would induce high heat stress. The further study would be established whether short persistency of lactation occurring in $87.5 \%$ HF cows is due to the effect of high ambient temperatures or the less stimulant effect of bovine somatotropin or combination of both of these factors during lactation advances. Environmental modifications are needed to minimize the effects of heat stress and that will maintain potentially increased milk yields because of bST technology (West, 1994). Few data are available concerning glucose utilization by the udder, under the effect of cooling and supplementation of rbST in crossbred Holstein cattle. Therefore, the present study was designed to investigate the mechanisms of milk secretion relating to intracellular metabolism of glucose in the mammary gland and body glucose metabolism during rbST supplementation in $87.5 \%$ HF cows housing under mistyfan cooling system.

\section{MATERIALS AND METHODS}

Animals and managements: Ten primiparous, crossbred $87.5 \%$ Holstein cattle were randomly divided into two groups of five animals each. Animals in the control group were housed in the Normal Shade (NS) in individual stall, while animals in the experimental group were housed in shade with using mister and fans cooling to reduce the environmental temperature (MF). The MF barn had two sets of misters and fans cooling system, which each system consisted of a 26 inch diameter blade fan circulating 7,200 $\mathrm{ft}^{3} \mathrm{~min}^{-1}$ of air, with oscillation coverage of $180^{\circ}$. The amount of water discharged from 4 spray heads was $7.5 \mathrm{~L} \mathrm{~h}^{-1}$ and side of mist droplet 0.01 $\mathrm{mm}$. Animal were exposed to $\mathrm{MF}$ for $45 \mathrm{~min}$ at $15 \mathrm{~min}$ intervals from 0600-1800 h. At night, animals were exposed to MFC for $15 \mathrm{~min}$ at $45 \mathrm{~min}$ intervals from 1800-0600 h. Animals in each group were fed with the same ration of TMR (Table 1) twice daily throughout the experiment. Each day, the diet was given in equal portion at about 0600 and $1700 \mathrm{~h}$ when animal were milked. Water was available at all times. All animals were weighed monthly throughout the experiment.

The study was performed under a protocol approved by ethic committee of Faculty of Veterinary Science, Chulalongkorn University. The procedures used in the present study were formulated to comply with international standards and are in accordance with the principles and guidelines of the National Research Council of Thailand.

Experimental procedures: The diagram illustrating the time course of the experiment is shown in Fig. 1. The experiments were carried out throughout lactating periods in each group. The experiment in each group was divided into 3 stages, namely early-(Days 65-95 postpartum), mid-(Days 125-155 postpartum) and late lactating stages (Days 185-215 postpartum). 
Am. J. Biochem. \& Biotech., 6 (3): 213-230, 2010

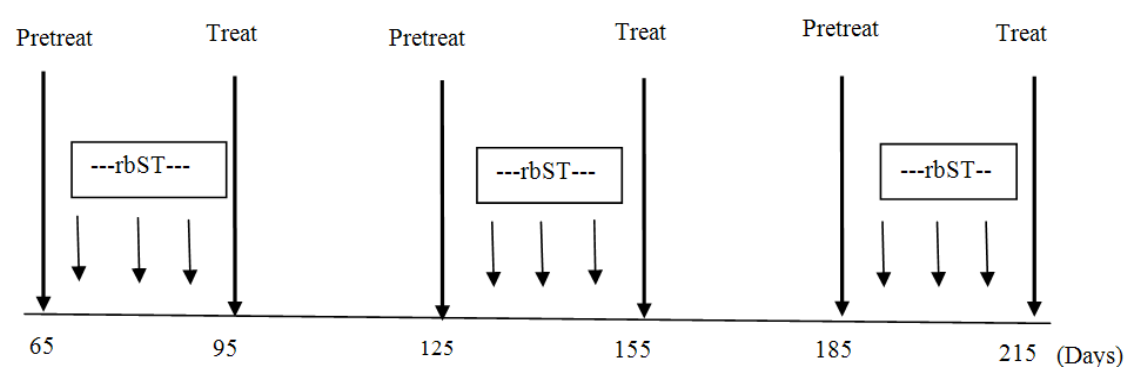

Fig. 1: Diagram illustrating the time course of studies in each cow supplemented with rbST at different stages of lactation. Pretreat $=$ timed study for pre-treatment; Treat $=$ timed study for treatment

Table 1: Ingredients and nutrient compositions of the TMR diet

\begin{tabular}{lc}
\hline Ingredients & $\mathrm{Kg}$ (as fed basis) \\
\hline Pine apple waste & 50.0 \\
Soybean meal & 23.0 \\
Rice bran & 3.0 \\
Cotton seed & 20.0 \\
Lime stone & 1.4 \\
Di-calcium phosphate & 1.4 \\
Sodium bicarbonate & 0.3 \\
Potassium chloride & 0.1 \\
Mineral and vitamin premix & 0.8 \\
Total & 100.0 \\
Nutrient compositions & \\
Dry matter (\%) & 39.1 \\
Ash (\% DM) & 7.3 \\
Organic matter (\% DM) & 92.7 \\
Crude protein (\% DM) & 18.0 \\
Acid detergent fiber (\% DM) & 20.1 \\
Neutral detergent fiber (\% DM) & 33.9 \\
\hline
\end{tabular}

The pretreatment study was conducted on the starting day of each lactating stage. At the end of the pretreatment, within the same day, the animal was injected with the first dose subcutaneous injection of $500 \mathrm{mg}$ of recombinant bovine Somatotropin (rbST) (POSILAC, Monsanto, USA). Subsequently, the animal was injected with two consecutive doses injections of rbST in every 2 weeks. Thereafter, within 2 days after the third injection, the treatment study was conducted. The pretreatment, 3 doses of injections and the treatment periods were performed during the first 30 days and the same procedures were followed for each lactating stage. During the last 30 days of each lactating stage, no experiments were conducted in order to allow the milk yield from the effect of rbST treatment to return to the control level (Kirchgessner et al., 1991).

Rectal temperature and respiration rate of individual animals were determined at the same time as recording ambient temperature. Ambient temperature and relative humidity were measured weekly throughout the experiment. The Temperature Humidity Index (THI) was calculated according to West (1994), where: $\mathrm{THI}=\mathrm{db}-(0.55-0.55 \mathrm{RH})(\mathrm{db}-58)$ with $\mathrm{db}=$ dry bulb temperature $\left({ }^{\circ} \mathrm{F}\right)$ and $\mathrm{RH}=$ relative humidity. $\mathrm{On}$ each specified day, measurements of mammary blood flow, glucose metabolism and the utilization of glucose by the mammary gland were carried out at around 10.00 $\mathrm{h}$. Both ear vein and milk vein were catheterized with the non-radiopaque intravenous catheters, gauge $18 \mathrm{G}$ (Surflo, Terumo Europe N.V., Belgium) under local anesthesia for infusion of solution. An arterial blood sample was collected from the coccygeal vessel by venipuncture with a \# 21 needle into heparinized tube. In the present study, blood sample from either tail vessel can be accounted for arterial blood sample. Since, it has been demonstrated in dairy cattle by Emery et al. (1965) that concentrations metabolites such as glucose and acetate in tail arterial blood were similar to those of tail venous blood. Blood samples from arterial and mammary venous blood in heparinized tube were kept in crushed ice and then centrifuge at $3000 \mathrm{rpm}$ for $30 \mathrm{~min}$ at $4^{\circ} \mathrm{C}$. Plasma samples were collected and frozen at $-40^{\circ} \mathrm{C}$ in aliquots until time of assays for measurements the concentration of metabolites.

Glucose turnover measurements: The study of glucose kinetic and efficiency of glucose utilization by the mammary gland during rbST supplementation in both cooled and non-cooled cows were performed at different stages of lactation. Glucose kinetic studies were carried out by using continuous infusion of both $\left[\mathrm{U}-{ }^{14} \mathrm{C}\right]$-glucose and $\left[3-{ }^{3} \mathrm{H}\right]$-glucose solution as described previously by Chaiyabutr et al. (1998). Briefly, at about $10.00 \mathrm{~h}$ of the specified day, a priming dose of radioactive glucose in $20 \mathrm{~mL}$ of sterile NSS containing $30 \mu \mathrm{Ci}\left[3-{ }^{3} \mathrm{H}\right]$-glucose and $15 \mu \mathrm{Ci}\left[\mathrm{U}-{ }^{14} \mathrm{C}\right]-$ glucose was administered intravenously via the ear vein catheter and followed by a continuous infusion of

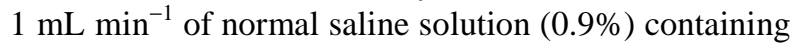
$0.7 \mu \mathrm{Ci} \mathrm{mL}{ }^{-1}$ of $\left[\mathrm{U}_{-}{ }^{14} \mathrm{C}\right]$-glucose and $1.5 \mu \mathrm{Ci} \mathrm{mL}^{-1}$ of [3- $\left.{ }^{3} \mathrm{H}\right]$-glucose for $3 \mathrm{~h}$. (Peristatic pump; EYLA Model $3)$. During the last $1 \mathrm{~h}(1200-1300 \mathrm{~h})$ of continuous infusion, three sets of blood samples were collected at 
20 min intervals. A venous blood sample was collected from the milk vein via a catheter while an arterial blood sample was collected from the coccygeal vessel by venipuncture with a \# 21 needle. Blood samples in heparinized tubes were kept in crushed ice for chemical studies. Milk secretion was recorded for the last $1 \mathrm{~h}$ of continuous infusion. Milk samples were used for measurement of radioactive glucose incorporation into other milk components. Milk yield was recorded by weight.

Mammary blood flow measurement: Blood flow through half of the udder were performed in duplicated by dye dilution technique using dye T-1824 (Evans blue) by a short term continuous infusion into the milk vein as described by Chaiyabutr et al. (1997). The rate of blood flow through half of the udder was calculated from plasma sample and the value of packed cell volume using the equation derived by Thompson and Thomson (1977). Quarter milking showed that the yields of the two halves of the udder were similar. Mammary blood flow was therefore calculated by doubling the flow measured in one milk vein (Bickerstaffe et al., 1974). Packed cell volume was measured after centrifugation of the blood in a microcapillary tube.

Chemical methods: Radiochemicals for $\left[\mathrm{U}-{ }^{14} \mathrm{C}\right]-$ glucose and $\left[3-{ }^{3} \mathrm{H}\right]$-glucose were obtained from the Radiochemical Center, Amersham Bucks, UK. The specific activity of labeled plasma glucose was determined by the method described by Chaiyabutr and Buranakarl (1989). The plasma glucose concentration was measured using enzymatic oxidation in the presence of glucose oxidase (Human $\mathrm{GmBH}$, Germany). Plasma free fatty acid were determined by colorimetry after plasma extraction with chloroform, heptane and methanol and TAN solution (Wang et al., 2004). Plasma triacylglycerol concentration was determined by enzymatic colorimetric test (Triglyceride liquicolor, Wiesbaden, Germany). The concentration of milk lactose was determined by spectrophotometry (Teles et al., 1978). Lactose radioactivity was determined after isolation by the hydrolysis method (Wood et al., 1965). Milk fatty acids was extracted from $1 \mathrm{ml}$ of an aliquot thawed milk in $2 \mathrm{~mL}$ of Dole's solution (Dole, 1956), (iso-propanol 40: n-heptane 10: $1 \mathrm{~N} \mathrm{H}_{2} \mathrm{SO}_{4} 1$, v/v) shaking in water bath for $30 \mathrm{~min}$. After $1 \mathrm{ml}$ hexane and $1 \mathrm{ml}_{2} \mathrm{O}$ was added to the vial and shaking, the upper layer containing fatty acids was transferred into two vials for radioactivity assay and for determination of milk fatty acids concentration. Milk extraction solution in counting vial with a scintillation cocktail was measured radioactivity of ${ }^{14} \mathrm{C}$ and ${ }^{3} \mathrm{H}$-fat by liquid scintillation counter. Other portion of milk extraction was used to determine milk fatty acids concentration by colorimetry according to Wang et al. (2004) using chloroform, heptane and methanol and TAN solution containing 1-(2-Thiazolylazo)-2-naphthol (Sigma-Aldrich). Milk fatty acid profiles were determined by gas chromatography (GC-2010 Gas Chromatograph, Shimazu) after extraction by chloroform and methanol (Christopherson and Glass, 1969) in comparison with the appropriate internal standard of pentadecanoic acid (C:15:0 fatty acid). The concentration of milk citrate was determined by spectrophotometry from tricarboxylic acid filtrate (White and Davies, 1963). Citrate radioactivity was determined after isolation by anion exchange chromatography (Hardwick et al., 1963).

Calculations: According to Chaiyabutr et al. (1980; 2008b), body glucose metabolism and intramammary glucose metabolism can be calculated as follow.

The glucose turnover rate in the whole animal $(\mathrm{T})$, expressed as $\mu \mathrm{mol} \mathrm{min}^{-1}$, was calculated from the equation:

$\mathrm{T}=\mathrm{I} / \mathrm{G}_{\mathrm{A}}$

Where:

$\mathrm{I}=$ Rate of infusion of $\left[\mathrm{U}-{ }^{14} \mathrm{C}\right]$ glucose or $\left[3-{ }^{3} \mathrm{H}\right]$ glucose $\left(\mu \mathrm{Ci} \min ^{-1}\right)$

$\mathrm{G}_{\mathrm{A}}=$ Specific activity of ${ }^{14} \mathrm{C}$ - or ${ }^{3} \mathrm{H}$-glucose in arterial plasma at equilibrium $\left(\mu \mathrm{Ci} \mu \mathrm{mol}^{-1}\right)$

Recycling of glucose carbon in the whole animal, expressed as \% glucose turnover, was calculated from the equation:

Recycling $=\left(T_{3}-T_{14}\right) \times 100 / T_{3}$

Where:

$\mathrm{T}_{3}=$ Reversible turnover of glucose calculated from $\left[3-{ }^{3} \mathrm{H}\right]$ glucose

$\mathrm{T}_{14}=$ Irreversible turnover of glucose calculated from $\left[\mathrm{U}-{ }^{14} \mathrm{C}\right]$ glucose

The metabolic glucose clearance rate in the whole animal $\left(\mathrm{C}_{\mathrm{G}}\right)$, expressed as $\mathrm{mL} \mathrm{min}^{-1}$, was calculated from the equation:

$\mathrm{C}_{\mathrm{G}}=\mathrm{T}_{3} / \mathrm{P}_{\mathrm{AG}}$

Where:

$\mathrm{T}_{3}=$ Reversible turnover of glucose calculated from $3-{ }^{3} \mathrm{H}$ glucose $\left(\mu \mathrm{mol} \mathrm{min}^{-1}\right)$ 
$\mathrm{P}_{\mathrm{AG}}=$ Arterial plasma glucose concentration $(\mu \mathrm{mol}$ $\mathrm{mL}^{-1}$ )

Uptake of glucose by the udder $\left(\mathrm{U}_{\mathrm{G}}\right)$, expressed as $\mu \mathrm{mol} \mathrm{min}^{-1}$, was calculated from the equation:

$$
\mathrm{U}_{\mathrm{G}}=\operatorname{MPFx}\left(\mathrm{P}_{\mathrm{A}} \mathrm{P}_{\mathrm{V}}\right)
$$

Where:

$\mathrm{MPF}=$ Mammary plasma flow $\left(\mathrm{mL} \mathrm{min}^{-1}\right)$

$\mathrm{P}_{\mathrm{A}}=$ Concentration of glucose in coccygeal arterial plasma ( $\left.\mu \mathrm{mol} \mathrm{mL} \mathrm{m}^{-1}\right)$

$\mathrm{P}_{\mathrm{V}}=$ Concentration of glucose of plasma from milk vein $\left(\mu \mathrm{mol} \mathrm{mL}{ }^{-1}\right)$

The milk component output (MO), expressed as

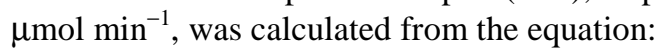

$\mathrm{MO}=\mathrm{Ms} \times \mathrm{Cc} / 1000$

Where:

Ms $=$ Milk secretion rate $\left(\mathrm{Ml} \mathrm{min}{ }^{-1}\right)$

$\mathrm{Cc}=$ Concentration of components in milk $\left(\mu \mathrm{mol} \mathrm{L}{ }^{-1}\right)$

Incorporation (A) of radioactivity from glucose into milk components was calculated from the equation:

$$
\mathrm{A}=\mathrm{M}_{\mathrm{A}} / \mathrm{G}_{\mathrm{A}} \times \mathrm{t}
$$

Where:

A = Incorporation of radioactivity from glucose into

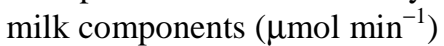

$\mathrm{M}_{\mathrm{A}}=$ Total activity of ${ }^{3} \mathrm{H}$ or ${ }^{14} \mathrm{C}$ in the milk components $(\mu \mathrm{Ci})$

$\mathrm{G}_{\mathrm{A}}=$ Specific activity of ${ }^{14} \mathrm{C}$-or ${ }^{3} \mathrm{H}$-glucose in arterial plasma at equilibrium $\left(\mu \mathrm{Ci} \mu \mathrm{mol}^{-1}\right)$

$\mathrm{t}=$ Time of infusion (min)

Requirement of NADPH for fatty acid synthesis

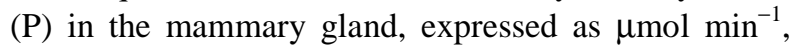
was calculated from the equation:

$\mathrm{P}_{\mathrm{NADPH}}=\sum\left[\mathrm{FFA}_{\mathrm{n}} \times(\mathrm{n}-2)\right]$

Where:

$\mathrm{n} \quad=$ Chain length of the fatty acid (6-16)

$\mathrm{FFA}_{\mathrm{n}}=$ Output in milk of fatty acid chain length $\mathrm{n}$ $\left(\mu \mathrm{mol} \min ^{-1}\right)$

Values for $\mathrm{FFA}_{\mathrm{n}}$ were calculated from all medium chain length fatty acids and $30 \%$ of $\mathrm{C}_{16}$-fatty acids (Annison and Linzell, 1964).
Net metabolism of Glucose Phosphorylation $\left(\mathrm{G}_{6} \mathrm{P}\right)$, expressed as $\mu \mathrm{mol} \mathrm{min}^{-1}$, was calculated from the equation:

$\mathrm{G}_{6} \mathrm{P}=\mathrm{U}_{\mathrm{G}}-\mathrm{L}$

Where:

$\mathrm{U}_{\mathrm{G}}=$ Mammary glucose uptake $\left(\mu \mathrm{mol} \mathrm{min}^{-1}\right)$

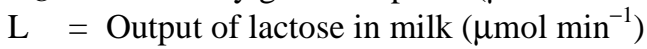

Net metabolism of glucose (B) to the galactose or glucose moiety of lactose, expressed as $\mu \mathrm{mol} \mathrm{min}^{-1}$, was calculated from the equation:

$\mathrm{B}=\mathrm{L}$

where, L output of lactose in milk ( $\left.\mu \mathrm{mol} \mathrm{min}^{-1}\right)$.

Metabolism of glucose via the pentose phosphate pathway (PC) was calculated from the equation:

$\mathrm{Y}=3 \mathrm{PC} /(1+2 \mathrm{PC})$

where, $\mathrm{Y}$ specific yield of ${ }^{14} \mathrm{CO}_{2}$ from $\left(1-{ }^{14} \mathrm{C}\right)$ glucose via the pentose phosphate pathway (Katz and Wood, 1963).

If the NADPH formed via PC were used exclusively for reductive biosynthesis of fatty acids, the ${ }^{3} \mathrm{H}$-incorporation from $\left[3-{ }^{3} \mathrm{H}\right]$ glucose into fatty acids would equal the ${ }^{14} \mathrm{CO}_{2}$ released from $\left[1-{ }^{14} \mathrm{C}\right]$ glucose via the pentose phosphate pathway (Katz et al., 1974). Metabolism of glucose via PC was therefore calculated from the equation:

$\mathrm{Z}=3 \mathrm{PC} /(1+2 \mathrm{PC})$

where, $\mathrm{Z}$ (Total ${ }^{3} \mathrm{H}$ in milk fatty acid) $/ \mathrm{t} \times \mathrm{G}_{\mathrm{A}} \times\left(\mathrm{U}_{\mathrm{G}}-\mathrm{L}\right)$

Net metabolism of glucose 6-phosphate via PC $\left(G_{P C}\right)$, expressed as $\mu \mathrm{mol} \mathrm{min}^{-1}$, was calculated from the equation:

$\mathrm{G}_{\mathrm{PC}}=\mathrm{G}_{6} \mathrm{P} \times \mathrm{PC}$

Net metabolism of glucose 6-phosphate via the Embden-Meyerhof pathway $\left(\mathrm{G}_{\mathrm{E}}\right)$, expressed as $\mu \mathrm{mol}$ $\min ^{-1}$, was calculated from the equation:

$\mathrm{G}_{\mathrm{E}}=\mathrm{G}_{6 \mathrm{p}}-\left(\mathrm{B}+\mathrm{G}_{\mathrm{PC}}\right)$

The ${ }^{3} \mathrm{H} /{ }^{14} \mathrm{C}$ ratio in the plasma and related product was calculated from the equation:

${ }^{3} \mathrm{H} /{ }^{14} \mathrm{C}$ glucose $\quad={ }^{3} \mathrm{H} /{ }^{14} \mathrm{C}$ in plasma glucose relative to ${ }^{3} \mathrm{H} /{ }^{14} \mathrm{C}$ ratio of 1 in the infusion 


$$
\begin{aligned}
{ }^{3} \mathrm{H} /{ }^{14} \mathrm{C} \text { lactose } & ={ }^{3} \mathrm{H} /{ }^{14} \mathrm{C} \text { in milk lactose relative } \\
& \text { to }{ }^{3} \mathrm{H} /{ }^{14} \mathrm{C} \text { ratio of } 1 \text { in the } \\
& \text { infusion } \\
= & 2\left({ }^{3} \mathrm{H} /{ }^{14} \mathrm{C} \text { lactose }\right)\left(-{ }^{3} \mathrm{H} /{ }^{14} \mathrm{C}\right. \\
& \text { glucose }) \\
= & { }^{3} \mathrm{H} /{ }^{14} \mathrm{C} \text { in milk citrate relative } \\
& \text { to }{ }^{3} \mathrm{H} /{ }^{14} \mathrm{C} \text { ratio of } 1 \text { in the } \\
& \text { infusion } \\
{ }^{3} \mathrm{H} /{ }^{14} \mathrm{C} \text { citrate } & \\
{ }^{3} \mathrm{H} /{ }^{14} \mathrm{C} \text { triacyglycerol }= & { }^{3} \mathrm{H} /{ }^{14} \mathrm{C} \text { in milk triacyglycerol } \\
& \text { relative to }{ }^{3} \mathrm{H} /{ }^{14} \mathrm{C} \text { ratio of } 1 \text { in } \\
& \text { the infusion }
\end{aligned}
$$

Statistical analysis: Individual cow data in each stage of lactation were adjusted for covariate effects with the data from pretreatment period before start of treatment period. The statistic analyses were performed using General Linear Model procedure of statistical software package SPSS (SPSS for windows, V14.0; SPSS Inc., Chicago, IL, USA) to study either effects or interaction effects of treatment and housing. The model used for each parameter analysis was:

$$
\begin{aligned}
\mathrm{Y}_{\mathrm{ijk}}= & \underset{\operatorname{Cov}_{\mathrm{k}}+\mathrm{e}_{\mathrm{ijkl}}}{\mu}+\mathrm{H}_{\mathrm{i}}+\mathrm{A}(\mathrm{H})_{\mathrm{il}}+\mathrm{B}_{\mathrm{j}}+(\mathrm{HB})_{\mathrm{ij}}+\mathrm{A}(\mathrm{HB})_{\mathrm{ijl}}+
\end{aligned}
$$

Where:

$\begin{array}{ll}\mathrm{Y}_{\mathrm{ijk}} & =\text { Observation } \\ \mu & =\text { Overall mean } \\ \mathrm{A}_{1} & =\text { Animal effect } \\ \mathrm{H}_{\mathrm{i}} & =\text { House effect as main plot }(\mathrm{i}=\mathrm{NS}, \mathrm{MF}) \\ \mathrm{A}(\mathrm{H})_{\mathrm{il}} & =\text { Main plot error (animal } 1 \text { in house } \mathrm{i})\end{array}$

$\mathrm{B}_{\mathrm{j}} \quad=$ Treatment effect $(\mathrm{rbST})$ as a split plot $(\mathrm{j}=$ with and without rbST supplementation)

$(\mathrm{HB})_{\mathrm{ij}}=$ Interaction effect between treatment and house

$\mathrm{A}(\mathrm{HB})_{\mathrm{ijl}}=$ Split plot error (animal 1 in house $\mathrm{i}$ and treatment $\mathrm{j}$ )

$\operatorname{Cov}_{\mathrm{k}}=$ Covariate effect

$\mathrm{e}_{\mathrm{ijk}} \quad=$ Residual error

The statistical significant differences of environmental parameters between NS and MF barn were determined by unpaired t-test. Statistical significance was declared at $\mathrm{p}<0.05$ and trends were declared at $0.05<\mathrm{p} \leq 0.10$.

\section{RESULTS}

Ambient temperature, relative humidity, Temperature Humidity Index (THI) respiratory rate and rectal temperature: Mean values of measurements at experimental site during periods of studies for daily

\begin{tabular}{|c|c|c|c|c|c|}
\hline \multirow[b]{2}{*}{ Parameter } & & & \multicolumn{2}{|l|}{ Treatments } & \multirow[b]{2}{*}{$\mathrm{p}$-value } \\
\hline & \multicolumn{2}{|c|}{ Stage of lactation } & $\mathrm{NS}(\mathrm{n}=5)$ & $\mathrm{MF}(\mathrm{n}=5)$ & \\
\hline Ambient & Early & $0900 \mathrm{~h}$ & $27.8 \pm 0.67$ & $27.3 \pm 0.68$ & 0.275 \\
\hline \multirow[t]{5}{*}{ Temperature $\left({ }^{\circ} \mathrm{C}\right)$} & & $1400 \mathrm{~h}$ & $34.9 \pm 1.29$ & $30.7 \pm 1.38$ & 0.001 \\
\hline & Mid & $0900 \mathrm{~h}$ & $28.3 \pm 0.67$ & $27.3 \pm 0.70$ & 0.052 \\
\hline & & $1400 \mathrm{~h}$ & $33.3 \pm 1.13$ & $30.4 \pm 0.89$ & 0.002 \\
\hline & Late & $0900 \mathrm{~h}$ & $28.4 \pm 0.90$ & $27.4 \pm 0.80$ & 1.000 \\
\hline & & $1400 \mathrm{~h}$ & $32.4 \pm 1.29$ & $29.0 \pm 1.09$ & 0.002 \\
\hline \multirow[t]{6}{*}{ Relative humidity (\%) } & Early & $0900 \mathrm{~h}$ & $79.3 \pm 3.67$ & $86.4 \pm 3.08$ & 0.011 \\
\hline & & $1400 \mathrm{~h}$ & $53.5 \pm 5.62$ & $67.9 \pm 7.91$ & 0.011 \\
\hline & Mid & $0900 \mathrm{~h}$ & $78.7 \pm 2.83$ & $84.4 \pm 2.86$ & 0.013 \\
\hline & & $1400 \mathrm{~h}$ & $58.8 \pm 3.04$ & $73.5 \pm 5.88$ & 0.001 \\
\hline & Late & $0900 \mathrm{~h}$ & $75.4 \pm 3.94$ & $82.4 \pm 3.52$ & 0.018 \\
\hline & & $1400 \mathrm{~h}$ & $60.9 \pm 6.71$ & $71.8 \pm 8.81$ & 0.059 \\
\hline Temperature & Early & $0900 \mathrm{~h}$ & $78.6 \pm 0.73$ & $78.6 \pm 0.88$ & 1.000 \\
\hline \multirow[t]{5}{*}{ Humidity Index (THI) } & & $1400 \mathrm{~h}$ & $85.4 \pm 1.10$ & $81.9 \pm 1.67$ & 0.001 \\
\hline & Mid & $0900 \mathrm{~h}$ & $79.3 \pm 0.88$ & $78.4 \pm 0.99$ & 0.176 \\
\hline & & $1400 \mathrm{~h}$ & $84.0 \pm 0.97$ & $82.4 \pm 1.17$ & 0.046 \\
\hline & Late & $0900 \mathrm{~h}$ & $78.9 \pm 1.10$ & $78.3 \pm 1.01$ & 0.395 \\
\hline & & $1400 \mathrm{~h}$ & $83.2 \pm 0.97$ & $79.9 \pm 1.01$ & 0.001 \\
\hline
\end{tabular}
temperatures, humidities and THI are shown in Table 2. The rectal temperature and respiratory rate are shown in Table 3. Average values of ambient temperature in the barn during the daytime in the morning $(0900 \mathrm{~h})$ between NS barn and MF barn were not significantly different, while ambient temperatures during $1400 \mathrm{~h}$ at NS barn were significantly higher than that of MF barn. The high relative humidity was apparent at morning and it decreased onwards from morning to evening in both NS and MF barns, whereas relative humidity in MF barn was significantly higher than that of NS barn.

Table 2: Ambient temperature, Relative humidity and temperature humidity index in Normal Shade (NS) barn and shade plus Misty-Fan cooling 
Am. J. Biochem. \& Biotech., 6 (3): 213-230, 2010

Table 3: Ambient temperature, Relative humidity, temperature humidity index, mean values of rectal temperature and respiratory rate of crossbred Holstein cows housing in Normal Shade (NS) and shade plus Misty-Fan Cooling (MFC)

\begin{tabular}{|c|c|c|c|c|c|c|c|c|c|c|}
\hline \multirow[b]{2}{*}{ Parameter } & \multirow{2}{*}{$\begin{array}{l}\text { Stages of } \\
\text { lactation }\end{array}$} & & \multicolumn{2}{|l|}{ NS } & \multicolumn{2}{|l|}{ MFC } & \multirow[b]{2}{*}{ SEM } & \multicolumn{3}{|l|}{${ }^{1}$ Effect } \\
\hline & & & Pre & $\mathrm{rbST}$ & Pre & $\mathrm{rbST}$ & & $\mathrm{rbST}$ & MFC & rbSTxMFC \\
\hline \multicolumn{11}{|c|}{ Rectal temperature $\left({ }^{\circ} \mathbf{C}\right)$} \\
\hline & Early & $0900 \mathrm{~h}$ & 38.5 & 38.9 & 38.1 & 38.5 & 0.08 & 0.003 & 0.032 & 1.000 \\
\hline & & $1400 \mathrm{~h}$ & 39.4 & 40.0 & 39.0 & 39.4 & 0.21 & 0.061 & 0.037 & 0.817 \\
\hline & Mid & $0900 \mathrm{~h}$ & 38.5 & 39.0 & 38.0 & 38.3 & 0.08 & 0.001 & 0.024 & 0.258 \\
\hline & & $1400 \mathrm{~h}$ & 39.7 & 40.1 & 38.6 & 39.5 & 0.13 & 0.002 & 0.002 & 0.090 \\
\hline & Late & $0900 \mathrm{~h}$ & 38.5 & 38.8 & 38.0 & 38.3 & 0.10 & 0.015 & 0.007 & 0.723 \\
\hline & & $1400 \mathrm{~h}$ & 39.2 & 39.9 & 38.4 & 38.8 & 0.16 & 0.016 & 0.015 & 0.309 \\
\hline \multicolumn{11}{|c|}{ Respiratory rate (breaths/min) } \\
\hline & Early & $0900 \mathrm{~h}$ & 40.0 & 42.5 & 35.0 & 38.0 & 0.56 & 0.003 & 0.003 & 0.670 \\
\hline & & $1400 \mathrm{~h}$ & 73.0 & 82.3 & 55.5 & 68.0 & 4.13 & 0.039 & 0.023 & 0.708 \\
\hline & Mid & $0900 \mathrm{~h}$ & 41.2 & 45.8 & 36.4 & 40.4 & 0.66 & 0.001 & 0.022 & 0.663 \\
\hline & & $1400 \mathrm{~h}$ & 73.6 & 77.2 & 49.0 & 57.6 & 1.96 & 0.018 & 0.001 & 0.294 \\
\hline & Late & $0900 \mathrm{~h}$ & 40.5 & 44.5 & 37.0 & 41.5 & 1.44 & 0.025 & 0.101 & 0.868 \\
\hline & & $1400 \mathrm{~h}$ & 71.5 & 80.0 & 54.3 & 59.3 & 1.09 & 0.001 & 0.019 & 0.159 \\
\hline
\end{tabular}

$\overline{\mathrm{SEM}}=$ Standard error of the mean. ${ }^{1}$ P-values for the effects; MFC $=$ Misty-Fan Cooling effect, $r b S T=$ rbST effect, MFC $\mathrm{x}$ rbST $=$ interaction effect of MFC and rbST

THI values at the MF barn in afternoon were significantly lower than that of NS barn. Cows in both groups exposed to high THI values (78.3-85.4) in both barns. Rectal temperature recording in the morning and afternoon (0900-1400 h) of cooled and non-cooled cows were significant different whether rbST injection or not. The rectal temperatures of cooled cows were lower than those of non-cooled cows during afternoon $(1400 \mathrm{~h})$. There were significant increases in rectal temperature and respiration rate by the effect of supplemental rbST in different parts of the day. The respiratory rates of cooled cows were significantly lower than those of non-cooled cows throughout experimental periods.

Milk yield, milk compositions and its secretion: Milk yield, milk compositions and its secretion of cooled and non-cooled cows are shown in Table 4. It is obvious that milk yield was significantly increased by rbST of both cooled and non-cooled cows, but it decreased as lactation advances. Milk lactose concentrations were not affected by rbST supplementation as compared with pretreatment in both groups or among stages of lactation in the same group. The ratio of lactose output/glucose uptake were not different in comparison between cooled and non-cooled cows whether supplemental rbST or not in each stage of lactation, but it showed tendency to decrease as lactation advances., The milk lactose secretion was significantly increased by rbST in both cooled and non-cooled cows in eac stage of lactation. The milk citrate concentration was significantly increased during supplemental rbST in early lactation, while its significantly decreased in late lactation in both cooled and non-cooled cows. However, during early and mid lactation, the secretions of milk citrate were significantly increased by rbST in both cooled and non-cooled cows. The concentration triacylglycerol in milk had tendency to increase during supplemental rbST, but a significant increases were apparent in early lactation in both groups. The secretions of milk triacylglycerol were significantly increased in both cooled and non-cooled cows during rbST supplementation in each stage of lactation.

Mammary plasma flow, plasma glucose concentration, mammary glucose uptake and percentage of glucose extraction: The utilization of glucose across the mammary gland during rbST supplementation in both cooled and non-cooled cows are shown in Table 5. Mammary plasma flow of both cooled and non-cooled cows were significantly increased by rbST administration in each stage of lactation. During rbST supplementation mammary glucose uptake increased in each stage of lactation in both cooled and non-cooled cows. The mammary glucose uptake of both non-cooled and cooled cows were significantly increased during supplemental rbST in mid and late lactations by average $37 \%$ and $34 \%$, respectively. Plasma glucose concentrations were not affected by rbST throughout lactation in both cooled and non-cooled cows. There were no significant changes in $\mathrm{A}-\mathrm{V}$ concentration differences for glucose across the mammary gland during rbST supplementation in each stage of lactation. The percentage of glucose extraction was not influenced by the supplementation of rbST in both groups.

Glucose turnover and related variables: Simultaneous estimation of the total glucose entry rate using $3-\left[{ }^{3} \mathrm{H}\right]$ glucose infusion and the utilization rate of glucose using $\left[\mathrm{U}-{ }^{14} \mathrm{C}\right]$ glucose infusion of both cooled and non-cooled cows supplemental rbST are shown in Table 6. 
Am. J. Biochem. \& Biotech., 6 (3): 213-230, 2010

Table 4: Milk yield, milk compositions and secretion for milk lactose, milk citrate and milk triacylglycerol during rbST administration at different stages of lactation of cows housing in Normal Shade (NS) and shade plus Misty-Fan Cooling (MFC)

\begin{tabular}{|c|c|c|c|c|c|c|c|c|c|}
\hline \multirow[b]{2}{*}{ Parameter } & \multirow{2}{*}{$\begin{array}{l}\text { Stages } \\
\text { of lactation }\end{array}$} & \multicolumn{2}{|l|}{ NS } & \multicolumn{2}{|l|}{ MFC } & \multirow[b]{2}{*}{ SEM } & \multicolumn{3}{|l|}{${ }^{1}$ Effect } \\
\hline & & Pre & $\mathrm{rbST}$ & Pre & $\mathrm{rbST}$ & & $\mathrm{rbST}$ & MFC & rbSTxMFC \\
\hline \multicolumn{10}{|c|}{ Milk yield $\left(\mathrm{kg} \mathrm{day}^{-1}\right)$} \\
\hline & Early & 13.39 & 15.43 & 14.82 & 15.84 & 0.31 & 0.001 & 0.684 & 0.140 \\
\hline & Mid & 11.13 & 13.10 & 13.79 & 15.73 & 0.54 & 0.003 & 0.269 & 0.549 \\
\hline & Late & 10.31 & 11.77 & 11.29 & 15.00 & 0.61 & 0.003 & 0.372 & 0.101 \\
\hline \multicolumn{10}{|c|}{ Lactose concentration ( $\left.\mathrm{mmol} \mathrm{L}^{-1}\right)$} \\
\hline & Early & 132.5 & 135.60 & 133.20 & 134.00 & 1.51 & 0.231 & 0.833 & 0.467 \\
\hline & Mid & 129.3 & 130.60 & 130.50 & 131.20 & 1.29 & 0.658 & 0.536 & 0.195 \\
\hline & Late & 130.5 & 129.70 & 131.70 & 133.60 & 1.68 & 0.769 & 0.338 & 0.448 \\
\hline \multicolumn{10}{|c|}{ Milk lactose secretion $\left(\mu \mathrm{mol} \mathrm{min}{ }^{-1}\right)$} \\
\hline & Early & 1230.3 & 1458.40 & 1367.70 & 1471.30 & 36.12 & 0.002 & 0.716 & 0.123 \\
\hline & Mid & 999.2 & 1188.00 & 1249.70 & 1497.50 & 48.38 & 0.003 & 0.225 & 0.100 \\
\hline & Late & 936.6 & 1066.30 & 1028.60 & 1392.50 & 57.35 & 0.003 & 0.347 & 0.075 \\
\hline \multicolumn{10}{|c|}{ Lactose output/Glucose uptake (\%) } \\
\hline & Early & 65.1 & 70.40 & 60.10 & 57.70 & 5.60 & 0.799 & 0.537 & 0.510 \\
\hline & Mid & 62.8 & 48.80 & 66.40 & 54.60 & 5.90 & 0.678 & 0.994 & 0.702 \\
\hline & Late & 40.8 & 34.40 & 36.70 & 43.90 & 3.00 & 0.903 & 0.668 & 0.055 \\
\hline \multicolumn{10}{|c|}{ Milk citrate concentration $\left(\mathrm{mmol} \mathrm{L}^{-1}\right)$} \\
\hline & Early & 4.24 & 4.54 & 4.22 & 4.85 & 0.15 & 0.014 & 0.305 & 0.303 \\
\hline & Mid & 4.7 & 4.71 & 5.67 & 5.78 & 0.11 & 0.575 & 0.016 & 0.645 \\
\hline & Late & 4.74 & 4.14 & 5.24 & 4.38 & 0.15 & 0.001 & 0.042 & 0.404 \\
\hline \multicolumn{10}{|c|}{ Milk citrate secretion $\left(\mu \mathrm{mol} \mathrm{min}{ }^{-1}\right)$} \\
\hline & Early & 39.51 & 48.81 & 43.81 & 52.95 & 1.74 & 0.001 & 0.578 & 0.965 \\
\hline & Mid & 36.21 & 42.16 & 54.48 & 67.00 & 2.82 & 0.011 & 0.078 & 0.277 \\
\hline & Late & 33.72 & 33.90 & 41.39 & 45.56 & 2.26 & 0.364 & 0.228 & 0.402 \\
\hline \multicolumn{10}{|c|}{ Milk triacylglycerol concentration $\left(\mathrm{mmol} \mathrm{L}^{-1}\right)$} \\
\hline & Early & 42.36 & 48.50 & 45.95 & 58.66 & 3.87 & 0.041 & 0.361 & 0.420 \\
\hline & Mid & 58.77 & 56.92 & 57.53 & 64.99 & 3.12 & 0.395 & 0.699 & 0.174 \\
\hline & Late & 61.13 & 69.36 & 54.67 & 66.41 & 5.61 & 0.113 & 0.503 & 0.762 \\
\hline \multicolumn{10}{|c|}{ Milk triacylglycerol secretion $\left(\mu \mathrm{mol} \min ^{-1}\right)$} \\
\hline & Early & 374.05 & 491.3 & 483.14 & 632.77 & 40.09 & 0.010 & 0.105 & 0.697 \\
\hline & Mid & 446.56 & 510.5 & 519.84 & 710.27 & 48.33 & 0.030 & 0.1 & 0.227 \\
\hline & Late & 433.02 & 569.36 & 415.35 & 688.55 & 81.45 & 0.036 & 0.59 & 0.425 \\
\hline
\end{tabular}

$\overline{\mathrm{SEM}}=$ Standard Error of the Mean; ${ }^{1}$ P-values for the effects; MFC = Misty-Fan Cooling effect; $r$ rST $=$ rbST effect; MFC x rbST = Interaction effect of MFC and rbST

Table 5: Mammary plasma flow, arterial plasma glucose concentration, mammary glucose uptake and percentage of glucose extraction during rbST administration at different stages of lactation of cows housing in Normal Shade (NS) and shade plus Misty-Fan Cooling (MFC)

\begin{tabular}{|c|c|c|c|c|c|c|c|c|c|}
\hline \multirow[b]{2}{*}{ Parameter } & \multirow{2}{*}{$\begin{array}{l}\text { Stages of } \\
\text { lactation }\end{array}$} & \multicolumn{2}{|l|}{ NS } & \multicolumn{2}{|l|}{ MFC } & \multirow[b]{2}{*}{ SEM } & \multicolumn{3}{|c|}{${ }^{1}$ Effect } \\
\hline & & Pre & $\mathrm{rbST}$ & Pre & rbST & & $\mathrm{rbST}$ & MFC & rbSTxMFC \\
\hline \multicolumn{10}{|c|}{ Mammary plasma flow $\left(\mathrm{mL} \min ^{-1}\right)$} \\
\hline & Early & 3748.00 & 4030.00 & 3923.00 & 5024.00 & 186.00 & 0.006 & 0.561 & 0.060 \\
\hline & Mid & 3139.00 & 3871.00 & 3164.00 & 4141.00 & 303.00 & 0.023 & 0.822 & 0.696 \\
\hline & Late & 2817.00 & 3843.00 & 3389.00 & 3792.00 & 185.00 & 0.005 & 0.676 & 0.131 \\
\hline \multicolumn{10}{|c|}{ Plasma glucose $\left(\mu \mathrm{mol} \mathrm{mL^{-1 } )}\right.$} \\
\hline & Early & 3.73 & 3.51 & 3.64 & 3.48 & 0.10 & 0.098 & 0.883 & 0.763 \\
\hline & Mid & 3.55 & 3.40 & 3.52 & 3.67 & 0.10 & 0.992 & 0.719 & 0.159 \\
\hline & Late & 3.49 & 3.52 & 3.82 & 3.77 & 0.09 & 0.918 & 0.286 & 0.646 \\
\hline \multicolumn{10}{|c|}{$\mathrm{A}-\mathrm{V}\left(\mu \mathrm{mol} \mathrm{mL^{-1 } )}\right.$} \\
\hline & Early & 0.66 & 0.67 & 0.76 & 0.61 & 0.08 & 0.485 & 0.858 & 0.261 \\
\hline & Mid & 0.62 & 0.58 & 0.74 & 0.72 & 0.07 & 0.810 & 0.480 & 0.605 \\
\hline & Late & 0.78 & 0.86 & 0.81 & 0.80 & 0.08 & 0.552 & 0.650 & 0.352 \\
\hline \multicolumn{10}{|c|}{ Mammary glucose uptake $\left(\mu \mathrm{mol} \mathrm{min}^{-1}\right)$} \\
\hline & Early & 2299.00 & 2651.00 & 2438.00 & 2653.00 & 212.00 & 0.168 & 0.766 & 0.632 \\
\hline & Mid & 1879.00 & 2437.00 & 1881.00 & 2745.00 & 355.00 & 0.042 & 0.624 & 0.982 \\
\hline & Late & 2183.00 & 3235.00 & 2475.00 & 2936.00 & 253.00 & 0.051 & 0.530 & 0.203 \\
\hline \multicolumn{10}{|c|}{ Percentage of mammary glucose extraction $(\%)$} \\
\hline & Early & 16.70 & 18.60 & 19.30 & 16.90 & 1.58 & 0.984 & 0.816 & 0.164 \\
\hline & Mid & 17.10 & 16.70 & 19.60 & 18.80 & 1.57 & 0.696 & 0.461 & 0.398 \\
\hline & Late & 22.20 & 24.40 & 21.50 & 21.50 & 1.62 & 0.530 & 0.901 & 0.373 \\
\hline
\end{tabular}

$\overline{\mathrm{SEM}}=$ Standard Error of the Mean ${ }^{1}{ }^{\mathrm{p}}$-values for the effects; MFC = Misty-Fan Cooling effect; $r b S T=$ rbST effect; MFC $\mathrm{x}$ rbST $=$ Interaction effect of MFC and rbST 
Am. J. Biochem. \& Biotech., 6 (3): 213-230, 2010

Table 6: Glucose turnover rate, glucose-C-recycling, plasma glucose clearance, non-mammary glucose utilization and body weight during rbST administration at different stages of lactation of Holstein cows housing in Normal Shade (NS) and shade plus Misty-Fan Cooling (MFC)

\begin{tabular}{|c|c|c|c|c|c|c|c|c|c|}
\hline \multirow[b]{2}{*}{ Parameter } & \multirow{2}{*}{$\begin{array}{l}\text { Stages of } \\
\text { lactation }\end{array}$} & \multicolumn{2}{|l|}{ NS } & \multicolumn{2}{|l|}{ MFC } & \multirow[b]{2}{*}{ SEM } & \multicolumn{3}{|l|}{${ }^{1}$ Effect } \\
\hline & & Pre & rbST & Pre & $\mathrm{rbST}$ & & rbST & MFC & rbSTxMFC \\
\hline \multicolumn{10}{|c|}{$\begin{array}{l}\text { Glucose turnover } \\
{\left[\mathrm{U}^{14} \mathrm{C}\right] \text { glucose }\left(\mu \mathrm{mol} \mathrm{min}^{-1}\right)}\end{array}$} \\
\hline & Early & 3377.4 & 3974.2 & 4547.8 & 4029.8 & 432.70 & 0.930 & 0.236 & 0.234 \\
\hline & Mid & 4380.8 & 4388.2 & 5851.6 & 5144.4 & 510.40 & 0.512 & 0.135 & 0.504 \\
\hline & Late & 4000.2 & 4302.8 & 5426.6 & 5428.8 & 414.90 & 0.723 & 0.110 & 0.727 \\
\hline \multicolumn{10}{|c|}{$\left[3-{ }^{3} \mathrm{H}\right]$ glucose $\left(\mu \mathrm{mol} \mathrm{min}{ }^{-1}\right)$} \\
\hline & Early & 4631.0 & 5064.6 & 5252.2 & 5032.4 & 539.80 & 0.848 & 0.703 & 0.562 \\
\hline & Mid & 5493.4 & 5488.8 & 7926.6 & 6026.4 & 598.10 & 0.150 & 0.134 & 0.152 \\
\hline & Late & 5309.2 & 5824.2 & 6707.0 & 8188.2 & 973.20 & 0.335 & 0.199 & 0.633 \\
\hline \multicolumn{10}{|c|}{ Glucose-C-recycling (\%) } \\
\hline & Early & 24.9 & 22.1 & 21.0 & 19.3 & 5.71 & 0.698 & 0.347 & 0.927 \\
\hline & Mid & 19.5 & 20.4 & 26.2 & 15.9 & 2.83 & 0.140 & 0.696 & 0.082 \\
\hline & Late & 28.5 & 24.2 & 18.6 & 30.1 & 4.58 & 0.453 & 0.776 & 0.126 \\
\hline \multicolumn{10}{|c|}{ Plasma glucose clearance $\left(\mathbf{m L} \min ^{-1}\right)$} \\
\hline & Early & 1403.9 & 1614.3 & 1391.9 & 1434.2 & 163.20 & 0.461 & 0.681 & 0.620 \\
\hline & Mid & 1603.0 & 1588.3 & 2357.3 & 1643.3 & 182.50 & 0.081 & 0.192 & 0.092 \\
\hline & Late & 1437.4 & 1737.8 & 1845.2 & 1881.2 & 283.40 & 0.252 & 0.264 & 0.866 \\
\hline \multicolumn{10}{|c|}{ Non mammary glucose utilization $\left(\mu \mathrm{mol} \mathrm{min}^{-1}\right)$} \\
\hline & Early & 2331.9 & 2413.6 & 2814.6 & 2379.1 & 659.40 & 0.754 & 0.898 & 0.746 \\
\hline & Mid & 3614.1 & 3052.4 & 4965.4 & 3281.3 & 406.70 & 0.014 & 0.207 & 0.336 \\
\hline & Late & 3126.2 & 2589.7 & 4231.6 & 3929.6 & 636.40 & 0.713 & 0.228 & 0.793 \\
\hline \multicolumn{10}{|c|}{ Non mammary glucose utilization $(\%)$} \\
\hline & Early & 49.6 & 47.8 & 52.5 & 44.2 & 7.00 & 0.395 & 0.754 & 0.787 \\
\hline & Mid & 65.4 & 59.1 & 74.3 & 53.8 & 3.32 & 0.001 & 0.903 & 0.207 \\
\hline & Late & 58.6 & 44.6 & 58.9 & 55.9 & 4.49 & 0.223 & 0.538 & 0.301 \\
\hline \multicolumn{10}{|c|}{ Body weight (kg) } \\
\hline & Early & 358.8 & 380.8 & 363.8 & 380.2 & 6.54 & 0.019 & 0.908 & 0.680 \\
\hline & Mid & 378.8 & 386.8 & 381.8 & 411.4 & 3.67 & 0.001 & 0.586 & 0.019 \\
\hline & Late & 391.0 & 400.2 & 418.6 & 427.4 & 6.16 & 0.182 & 0.297 & 0.975 \\
\hline
\end{tabular}
effect of MFC and rbST

The glucose entry and utilization rates were not affected by $\mathrm{rbST}$ in both cooled and non-cooled cows. The recycling of glucose- $\mathrm{C}$ showed no differences between cooled and non-cooled cows whether supplemental rbST or not. Plasma glucose clearance remained unchanged during rbST administration in both cooled and non-cooled cows. Both absolute values and percentage of utilization of glucose of non-mammary tissues of both cooled and non-cooled cows increased as lactation advanced, but it was significantly decreased by rbST during mid lactation. The body weights of both cooled and non-cooled cows whether supplemental rbST or not increased stepwise as lactation advances.

Utilization of glucose carbon in the mammary gland: Glucose uptake and incorporation into related products of lactose, citrate and triacylglycerol are shown in Table 7. Absolute values of the utilization of glucose carbon to milk lactose were increased by rbST in early and mid lactation of both cooled and noncooled cows, while it decreased in late lactation. However, the percentage of utilization of glucose carbon for synthesis of milk lactose was not affected by rbST in early and mid lactation, but the significant decrease was apparent in late lactation of both cooled and non-cooled cows. The absolute values and percentage of utilization of glucose carbon for synthesis of milk citrate were significantly lower in rbST-treated cows during mid and late lactation in both cooled and non-cooled cows. During supplementation of $\mathrm{rbST}$, the utilizations of glucose carbon for synthesis of milk triacylglycerol were higher in both cooled and noncooled cows in all stages of lactation.

Glucose metabolisms in different metabolic pathways in the udder: The effects of supplemental rbST and cooling on intracellular glucose metabolisms in the mammary gland are shown in Table 8. The incorporation of ${ }^{3} \mathrm{H}$ from $\left[3-{ }^{3} \mathrm{H}\right]$ glucose into fatty acids and the flux through the pentose phosphate pathway were increased by supplemental rbST in both cooled and non-cooled cows. These flux were also increased because of lactation advances neither cooling system nor rbST. Correction for the lower ${ }^{3} \mathrm{H} /{ }^{14} \mathrm{C}$ ratio in presenting intracellular glucose 6-phosphate still gave high flux values as lactation advances and during supplemental rbST in both cooled and non-cooled cows. The present results for the net metabolism of glucose 6-phosphate via the pentose phosphate pathway has been defined as glucose 6-phosphate metabolized according to the equation (Katz and Wood, 1963):

glucose 6-phosphate g lyceraldehyde 3-phosphate + $3 \mathrm{CO}_{2}$ 
Am. J. Biochem. \& Biotech., 6 (3): 213-230, 2010

Table 7: Utilization of glucose carbon in the udder during rbST administration at different stages of lactation of Holstein cows housing in Normal Shade (NS) and shade plus Misty-Fan Cooling (MFC)

\begin{tabular}{|c|c|c|c|c|c|c|c|c|c|}
\hline \multirow[b]{2}{*}{ Parameter } & \multirow[b]{2}{*}{$\begin{array}{l}\text { Stages of } \\
\text { lactation }\end{array}$} & \multicolumn{2}{|l|}{ NS } & \multicolumn{2}{|l|}{ MFC } & \multirow[b]{2}{*}{ SEM } & \multicolumn{3}{|c|}{${ }^{1}$ Effect } \\
\hline & & Pre & rbST & Pre & $\mathrm{rbST}$ & & $\mathrm{rbST}$ & MFC & rbSTxMFC \\
\hline \multicolumn{10}{|c|}{$\left[{ }^{14} \mathrm{C}\right]$ Glucose incorporation $\left(\mu \mathrm{mol} \mathrm{min}^{-1}\right)$ into: } \\
\hline \multicolumn{10}{|c|}{ Milk lactose } \\
\hline & Early & 1102.90 & 1633.50 & 1809.70 & 2372.50 & 254.96 & 0.009 & 0.323 & 0.601 \\
\hline & Mid & 1280.20 & 1405.70 & 1738.70 & 2113.40 & 237.83 & 0.856 & 0.602 & 0.452 \\
\hline & Late & 1369.70 & 1034.00 & 1661.60 & 874.10 & 223.11 & 0.059 & 0.652 & 0.675 \\
\hline \multicolumn{10}{|c|}{ Milk triacylglycerol } \\
\hline & Early & 78.18 & 135.81 & 165.25 & 236.94 & 38.69 & 0.163 & 0.010 & 0.760 \\
\hline & Mid & 126.85 & 217.62 & 197.00 & 197.66 & 29.82 & 0.244 & 0.660 & 0.251 \\
\hline & Late & 154.49 & 205.94 & 118.87 & 231.53 & 51.25 & 0.226 & 0.930 & 0.638 \\
\hline \multicolumn{10}{|l|}{ Milk citrate } \\
\hline & Early & 25.45 & 21.19 & 23.78 & 16.41 & 4.58 & 0.793 & 0.822 & 0.597 \\
\hline & Mid & 25.06 & 17.20 & 16.50 & 8.84 & 3.67 & 0.013 & 0.136 & 0.922 \\
\hline & Late & 25.43 & 16.67 & 20.81 & 18.13 & 2.59 & 0.052 & 0.704 & 0.024 \\
\hline \multicolumn{10}{|c|}{$\begin{array}{l}\text { Percentage of glucose carbon appearing as: } \\
\text { Milk lactose }\end{array}$} \\
\hline & Early & 52.50 & 64.60 & 73.60 & 88.60 & 34.93 & 0.261 & 0.080 & 0.718 \\
\hline & Mid & 81.30 & 58.50 & 91.90 & 77.90 & 19.45 & 0.628 & 0.377 & 0.831 \\
\hline & Late & 58.60 & 32.40 & 57.80 & 28.30 & 11.34 & 0.012 & 0.199 & 0.429 \\
\hline \multicolumn{10}{|c|}{ Milk triacylglycerol } \\
\hline & Early & 3.70 & 7.60 & 8.20 & 11.40 & 1.98 & 0.227 & 0.011 & 0.577 \\
\hline & Mid & 6.90 & 10.30 & 11.60 & 7.60 & 1.74 & 0.424 & 0.354 & 0.649 \\
\hline & Late & 6.70 & 6.40 & 4.90 & 8.40 & 2.28 & 0.632 & 0.655 & 0.590 \\
\hline \multicolumn{10}{|c|}{ Milk citrate } \\
\hline & Early & 1.46 & 1.09 & 0.98 & 0.750 & 0.38 & 0.556 & 0.714 & 0.853 \\
\hline & Mid & 1.56 & 0.91 & 1.07 & 0.380 & 0.22 & 0.005 & 0.135 & 0.468 \\
\hline & Late & 1.19 & 0.58 & 0.70 & 0.620 & 0.12 & 0.013 & 0.385 & 0.017 \\
\hline
\end{tabular}

$\overline{\mathrm{SEM}}=$ Standard Error of the Mean; ${ }^{1}$ p-values for the effects; MFC = Misty-Fan Cooling effect; rbST = rbST effect; MFC $\mathrm{x}$ rbST = Interaction effect of MFC and rbST

Table 8: Glucose metabolism in different metabolic pathway in the udder during rbST administration at different stages of lactation of Holstein cows housing in Normal Shade (NS) and shade plus Misty-Fan Cooling (MFC)

\begin{tabular}{|c|c|c|c|c|c|c|c|c|c|}
\hline \multirow[b]{2}{*}{ Parameter } & \multirow{2}{*}{$\begin{array}{l}\text { Stages of } \\
\text { lactation }\end{array}$} & \multicolumn{2}{|l|}{ NS } & \multicolumn{2}{|l|}{ MFC } & \multirow[b]{2}{*}{ SEM } & \multicolumn{3}{|c|}{${ }^{1}$ Effect } \\
\hline & & Pre & $\mathrm{rbST}$ & Pre & $\mathrm{rbST}$ & & $\mathrm{rbST}$ & MFC & rbSTxMFC \\
\hline \multicolumn{10}{|c|}{$\begin{array}{l}\text { Flux through the pentose phosphate pathway calculated as } \\
{ }^{3} \mathrm{H} \text { incorporation into milk fatty acid } \\
\text { (equivalent } \mu \mathrm{mol} \text { of glucose } \mathrm{min}^{-1} \text { ) }\end{array}$} \\
\hline & Early & 156.50 & 234.70 & 236.70 & 326.90 & 34.08 & 0.039 & 0.269 & 0.865 \\
\hline & Mid & 212.70 & 294.20 & 300.00 & 344.10 & 64.36 & 0.358 & 0.250 & 0.779 \\
\hline & Late & 421.30 & 412.90 & 376.00 & 282.90 & 68.33 & 0.479 & 0.415 & 0.552 \\
\hline \multicolumn{10}{|c|}{$\begin{array}{l}\text { Corrected }{ }^{3} \mathrm{H} \text { incorporation into milk fatty acid } \\
\text { (equivalent } \mu \mathrm{mol} \text { of glucose } \mathrm{min}^{-1} \text { ) }\end{array}$} \\
\hline & Early & 237.27 & 280.81 & 273.54 & 420.42 & 65.64 & 0.185 & 0.406 & 0.454 \\
\hline & Mid & 280.22 & 352.92 & 406.02 & 551.58 & 77.09 & 0.195 & 0.096 & 0.649 \\
\hline & Late & 537.57 & 572.53 & 472.91 & 420.03 & 103.24 & 0.933 & 0.501 & 0.682 \\
\hline \multicolumn{10}{|c|}{ 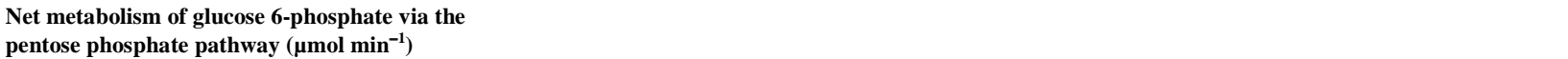 } \\
\hline & Early & 70.10 & 102.68 & 97.13 & 143.49 & 18.04 & 0.060 & 0.336 & 0.713 \\
\hline & Mid & 94.30 & 131.29 & 126.93 & 134.54 & 34.27 & 0.534 & 0.586 & 0.680 \\
\hline & Late & 181.80 & 170.62 & 155.28 & 106.89 & 36.28 & 0.435 & 0.355 & 0.622 \\
\hline \multicolumn{10}{|c|}{ Net metabolism of glucose 6-phosphate via the pentose phosphate pathway (\%) } \\
\hline & Early & 11.00 & 13.20 & 11.40 & 16.80 & 4.04 & 0.374 & 0.778 & 0.699 \\
\hline & Mid & 13.10 & 14.20 & 16.50 & 14.90 & 4.24 & 0.544 & 0.347 & 0.406 \\
\hline & Late & 12.50 & 8.70 & 9.70 & 6.20 & 2.60 & 0.195 & 0.409 & 0.952 \\
\hline \multicolumn{10}{|c|}{ Metabolism of glucose 6-phosphate via the galactose moiety of lactose (\%) } \\
\hline & Early & 81.60 & 90.10 & 67.70 & 74.90 & 10.10 & 0.459 & 0.317 & 0.951 \\
\hline & Mid & 87.10 & 87.40 & 97.20 & 78.30 & 16.30 & 0.583 & 0.972 & 0.571 \\
\hline & Late & 56.00 & 42.70 & 58.90 & 58.30 & 11.20 & 0.553 & 0.515 & 0.588 \\
\hline \multicolumn{10}{|c|}{ Metabolism of glucose 6-phosphate via Embden-Meyerhof pathway $(\mu \mathrm{mol} / \mathrm{min})$} \\
\hline & Early & -115.80 & -103.40 & -197.50 & -216.40 & 111.40 & 0.977 & 0.748 & 0.892 \\
\hline & Mid & -213.60 & 91.10 & -345.90 & -226.60 & 168.20 & 0.243 & 0.351 & 0.597 \\
\hline & Late & 124.30 & 465.70 & 321.3 & 111.60 & 139.30 & 0.649 & 0.713 & 0.083 \\
\hline \multicolumn{10}{|c|}{ Metabolism of glucose 6-phosphate via Embden-Meyerhof pathway (\%) } \\
\hline & Early & -22.50 & -42.10 & -43.00 & -25.90 & 11.40 & 0.914 & 0.949 & 0.146 \\
\hline & Mid & -25.60 & -12.40 & -61.10 & -61.40 & 21.60 & 0.774 & 0.370 & 0.762 \\
\hline & Late & 19.60 & 26.60 & 25.00 & 13.00 & 4.10 & 0.565 & 0.582 & 0.050 \\
\hline
\end{tabular}

SEM = Standard Error of the Mean; ${ }^{1}$ - -values for the effects; MFC = Misty-Fan Cooling effect; rbST = rbST effect; MFCxrbST = Interaction effect of MFC and rbST 
Am. J. Biochem. \& Biotech., 6 (3): 213-230, 2010

Table 9: Fatty acid composition of milk fat during rbST administration at different stages of lactation of Holstein cows housing in Normal Shade (NS) and shade plus Misty-Fan Cooling (MFC)

\begin{tabular}{|c|c|c|c|c|c|c|c|c|c|}
\hline \multirow[b]{2}{*}{$\begin{array}{l}\text { Stages } \\
\text { of lactation }\end{array}$} & \multirow[b]{2}{*}{$\begin{array}{l}\text { Fatty acid } \\
\text { chain length }\end{array}$} & \multicolumn{2}{|l|}{ NS } & \multicolumn{2}{|l|}{ MFC } & \multirow[b]{2}{*}{ SEM } & \multicolumn{3}{|l|}{${ }^{1}$ Effect } \\
\hline & & Pre & $\mathrm{rbST}$ & Pre & $\mathrm{rbST}$ & & $\mathrm{rbST}$ & MFC & rbSTxMFC \\
\hline \multicolumn{10}{|c|}{ Early lactation: $\left(\mu \mathrm{mol} \mathrm{mL}^{-1}\right)$} \\
\hline & C6 & 0.97 & 1.30 & 0.53 & 1.79 & 0.20 & 0.004 & 0.937 & 0.051 \\
\hline & $\mathrm{C} 8$ & 0.37 & 0.68 & 0.95 & 0.84 & 0.11 & 0.373 & 0.060 & 0.080 \\
\hline & $\mathrm{C} 10$ & 0.81 & 1.40 & 2.06 & 1.67 & 0.19 & 0.582 & 0.041 & 0.030 \\
\hline & $\mathrm{C} 12$ & 0.88 & 1.47 & 2.20 & 1.75 & 0.15 & 0.670 & 0.021 & 0.009 \\
\hline & $\mathrm{C} 14$ & 4.16 & 5.59 & 6.74 & 6.47 & 0.45 & 0.231 & 0.040 & 0.094 \\
\hline & $\mathrm{C} 16: 0$ & 16.67 & 21.64 & 22.38 & 25.35 & 1.30 & 0.016 & 0.131 & 0.464 \\
\hline & $\mathrm{C} 16: 1$ & 0.17 & 0.67 & 0.66 & 0.82 & 0.08 & 0.004 & 0.065 & 0.079 \\
\hline & C18:0 & 5.72 & 4.92 & 4.00 & 5.68 & 0.40 & 0.304 & 0.586 & 0.014 \\
\hline & $\mathrm{C} 18: 1$ & 11.94 & 12.05 & 8.91 & 16.89 & 1.58 & 0.037 & 0.605 & 0.033 \\
\hline & $\mathrm{C} 18: 2$ trans & 0.67 & 0.86 & 0.71 & 0.69 & 0.15 & 0.577 & 0.728 & 0.509 \\
\hline & $\mathrm{C} 18: 2$ cis & 1.64 & 0.91 & 0.80 & 0.86 & 0.38 & 0.408 & 0.325 & 0.327 \\
\hline & Total & 45.25 & 50.26 & 49.93 & 62.81 & 2.93 & 0.016 & 0.195 & 0.217 \\
\hline \multicolumn{10}{|c|}{ Mid lactation: $\left(\mu \mathrm{mol} \mathrm{mL}^{-1}\right)$} \\
\hline & C6 & 1.43 & 1.50 & 1.49 & 1.80 & 0.15 & 0.240 & 0.757 & 0.467 \\
\hline & $\mathrm{C} 8$ & 0.69 & 0.17 & 0.69 & 0.85 & 0.09 & 0.314 & 0.78 & 0.458 \\
\hline & $\mathrm{C} 10$ & 1.56 & 1.81 & 1.42 & 1.85 & 0.20 & 0.121 & 0.946 & 0.661 \\
\hline & $\mathrm{C} 12$ & 1.61 & 1.97 & 1.51 & 2.00 & 0.24 & 0.108 & 0.956 & 0.778 \\
\hline & $\mathrm{C} 14$ & 5.54 & 6.53 & 5.40 & 6.69 & 0.55 & 0.074 & 0.993 & 0.793 \\
\hline & C16:0 & 19.69 & 22.54 & 19.17 & 23.45 & 1.34 & 0.029 & 0.963 & 0.608 \\
\hline & $\mathrm{C} 16: 1$ & 0.61 & 0.77 & 0.81 & 1.00 & 0.07 & 0.029 & 0.203 & 0.854 \\
\hline & $\mathrm{C} 18: 0$ & 4.86 & 5.24 & 3.39 & 4.29 & 0.60 & 0.314 & 0.264 & 0.675 \\
\hline & $\mathrm{C} 18: 1$ & 9.07 & 10.91 & 10.43 & 13.77 & 1.00 & 0.033 & 0.048 & 0.478 \\
\hline & $\mathrm{C} 18: 2$ trans & 0.16 & 0.14 & 0.13 & 0.20 & 0.02 & 0.195 & 0.679 & 0.016 \\
\hline & $\mathrm{C} 18: 2 \mathrm{cis}$ & 0.91 & 1.02 & 0.58 & 0.82 & 0.08 & 0.083 & 0.038 & 0.477 \\
\hline & Total & 46.11 & 53.14 & 45.04 & 56.74 & 2.83 & 0.011 & 0.870 & 0.433 \\
\hline \multicolumn{10}{|c|}{ Late lactation: $\left(\mu \mathrm{mol} \mathrm{mL}^{-1}\right)$} \\
\hline & C6 & 1.54 & 1.69 & 1.50 & 1.91 & 0.11 & 0.029 & 0.876 & 0.255 \\
\hline & $\mathrm{C} 8$ & 0.68 & 0.66 & 0.72 & 0.96 & 0.05 & 0.048 & 0.268 & 0.027 \\
\hline & $\mathrm{C} 10$ & 1.51 & 1.47 & 1.47 & 2.10 & 0.08 & 0.008 & 0.335 & 0.004 \\
\hline & $\mathrm{C} 12$ & 1.65 & 1.72 & 1.53 & 2.19 & 0.07 & 0.001 & 0.438 & 0.003 \\
\hline & $\mathrm{C} 14$ & 6.08 & 5.89 & 5.37 & 6.75 & 0.33 & 0.113 & 0.912 & 0.047 \\
\hline & $\mathrm{C} 16: 0$ & 21.60 & 23.05 & 20.56 & 24.43 & 1.78 & 0.174 & 0.954 & 0.515 \\
\hline & $\mathrm{C} 16: 1$ & 0.84 & 1.01 & 0.89 & 1.10 & 0.15 & 0.252 & 0.749 & 0.888 \\
\hline & C18:0 & 5.29 & 4.82 & 4.50 & 6.36 & 0.67 & 0.326 & 0.747 & 0.118 \\
\hline & C18:1 & 12.30 & 14.67 & 13.37 & 19.63 & 1.17 & 0.006 & 0.289 & 0.134 \\
\hline & C18:2 trans & 0.21 & 0.20 & 0.23 & 0.27 & 0.02 & 0.478 & 0.371 & 0.135 \\
\hline & $\mathrm{C} 18: 2 \mathrm{cis}$ & 1.03 & 0.95 & 0.86 & 1.24 & 0.12 & 0.229 & 0.686 & 0.081 \\
\hline & Total & 53.10 & 55.76 & 51.89 & 66.05 & 4.03 & 0.070 & 0.553 & 0.191 \\
\hline
\end{tabular}

$\overline{\mathrm{SEM}}=$ Standard Error of the Mean; ${ }^{1} \mathrm{p}$-values for the effects; MF = Misty-Fan Cooling effect; rbST = rbST effect; MF x rbST = Interaction effect of MF and $\mathrm{rbST}$

According to this equation, complete metabolism of one molecule of glucose 6-phosphate would require three cycles of the pentose phosphate pathway. Therefore, the flux through the pathway would be three times for the net rate of glucose metabolized in the pentose phosphate pathway. The present results showed that the intracellular glucose phosphorylated by the mammary gland were metabolized more via the pentose phosphate pathway by rbST either in terms of absolute values or the percentage values in early and mid lactation. These values were declined in late lactation. Values of metabolism of glucose 6-phosphate via the galactose moiety of lactose were decreased as lactation advanced to late lactation neither cooling nor rbST in both groups. Metabolism of glucose 6-phosphate via the Embden-Meyerhof pathway was calculated in term of the proportion of metabolized glucose, which was considerable variation throughout stages of lactation in cooled and non-cooled cows. However, the absolute rate of metabolism of glucose via the EmbdenMeyerhof pathway appeared to increase in the late lactation in both cooled and non-cooled cows whether supplemental rbST or not, but the inclement was not statistical significant.

Milk fatty acid concentration: The data in Table 9 showed the marked increases in the total milk fatty acids concentrations during supplemental rbST in both cooled and non-cooled cows. The statistical significant effects of rbST on total milk fatty acids concentrations were apparent in early and mid lactation in both groups. The long chain length fatty acids $\left(\mathrm{C}_{16}-\mathrm{C}_{18}\right)$ concentrations in milk were significantly increased by supplemental rbST in both cooled and non-cooled cows in each stage of lactation. 
Am. J. Biochem. \& Biotech., 6 (3): 213-230, 2010

Table 10: NADPH production for fatty acid synthesis in the udder during rbST administration at different stages of lactation of Holstein cows housing in Normal Shade (NS) and shade plus Misty-Fan Cooling (MFC)

\begin{tabular}{|c|c|c|c|c|c|c|c|c|c|}
\hline \multirow[b]{2}{*}{ Parameter } & \multirow{2}{*}{$\begin{array}{l}\text { Stages of } \\
\text { lactation }\end{array}$} & \multicolumn{2}{|l|}{ NS } & \multicolumn{2}{|l|}{ MFC } & \multirow[b]{2}{*}{ SEM } & \multicolumn{3}{|c|}{${ }^{1}$ Effect } \\
\hline & & Pre & $\mathrm{rbST}$ & Pre & $\mathrm{rbST}$ & & $\mathrm{rbST}$ & MFC & rbSTxMFC \\
\hline \multirow{3}{*}{$\begin{array}{l}\text { Requirement of all NADPH for } \\
\text { fatty acid synthesis }(\mu \mathrm{mol} / \mathrm{min})\end{array}$} & Early & 1134.0 & 1761.0 & 1920.0 & 2067.0 & 134.00 & 0.020 & 0.203 & 0.112 \\
\hline & Mid & 1235.0 & 1698.0 & 1428.0 & 2150.0 & 181.00 & 0.011 & 0.539 & 0.495 \\
\hline & Late & 1240.0 & 1460.0 & 1154.0 & 2062.0 & 150.00 & 0.006 & 0.481 & 0.052 \\
\hline \multirow{3}{*}{$\begin{array}{l}\text { Requirement of all NADPH } \\
\text { formation from glucose via the } \\
\text { pentose phosphate pathway }(\%)\end{array}$} & Early & 16.7 & 18.5 & 19.5 & 24.9 & 3.14 & 0.286 & 0.482 & 0.594 \\
\hline & Mid & 25.6 & 26.5 & 31.6 & 25.6 & 7.36 & 0.744 & 0.667 & 0.651 \\
\hline & Late & 35.4 & 25.6 & 26.5 & 17.8 & 5.16 & 0.112 & 0.255 & 0.925 \\
\hline
\end{tabular}

SEM = Standard Error of the Mean; ${ }^{1}$-values for the effects; MFC =Misty-Fan Cooling effect;rbST = rbST effect; MFC x rbST = Interaction effect of MFC and rbST

Table 11: ${ }^{3} \mathrm{H} /{ }^{14} \mathrm{C}$ ratios in plasma glucose and related products during rbST administration at different stages of lactation of Holstein cows housing in Normal Shade (NS) and shade plus Misty-Fan Cooling (MFC)

\begin{tabular}{|c|c|c|c|c|c|c|c|c|c|}
\hline \multirow[b]{2}{*}{ Parameter } & \multirow{2}{*}{$\begin{array}{l}\text { Stage of } \\
\text { lactation }\end{array}$} & \multicolumn{2}{|l|}{ NS } & \multicolumn{2}{|l|}{ MFC } & \multirow[b]{2}{*}{ SEM } & \multicolumn{3}{|c|}{${ }^{1}$ Effect } \\
\hline & & Pre & $\mathrm{rbST}$ & Pre & $\mathrm{rbST}$ & & $\mathrm{rbST}$ & MFC & rbSTxMFC \\
\hline \multicolumn{10}{|c|}{ Plasma glucose } \\
\hline & Early & 0.76 & 0.81 & 0.86 & 0.82 & 0.08 & 0.973 & 0.393 & 0.589 \\
\hline & Mid & 0.80 & 0.82 & 0.74 & 0.68 & 0.04 & 0.653 & 0.217 & 0.317 \\
\hline & Late & 0.80 & 0.76 & 0.84 & 0.68 & 0.04 & 0.029 & 0.781 & 0.176 \\
\hline \multicolumn{10}{|c|}{ Milk lactose } \\
\hline & Early & 0.83 & 0.73 & 0.65 & 0.74 & 0.06 & 0.930 & 0.104 & 0.173 \\
\hline & Mid & 0.88 & 0.88 & 0.73 & 0.70 & 0.08 & 0.831 & 0.152 & 0.869 \\
\hline & Late & 0.72 & 0.60 & 0.71 & 0.71 & 0.08 & 0.493 & 0.539 & 0.471 \\
\hline \multicolumn{10}{|c|}{ Milk galactose } \\
\hline & Early & 0.86 & 0.87 & 0.60 & 0.66 & 0.07 & 0.576 & 0.047 & 0.715 \\
\hline & Mid & 0.83 & 0.93 & 0.72 & 0.73 & 0.11 & 0.638 & 0.231 & 0.677 \\
\hline & Late & 0.64 & 0.64 & 0.67 & 0.74 & 0.11 & 0.732 & 0.472 & 0.759 \\
\hline \multicolumn{10}{|c|}{ Milk triacylglycerol } \\
\hline & Early & 1.43 & 2.14 & 2.74 & 1.64 & 0.60 & 0.852 & 0.176 & 0.076 \\
\hline & Mid & 3.51 & 2.93 & 3.70 & 1.79 & 0.72 & 0.124 & 0.721 & 0.381 \\
\hline & Late & 2.45 & 2.61 & 3.12 & 1.90 & 0.50 & 0.327 & 0.976 & 0.206 \\
\hline & Early & \multicolumn{3}{|c|}{ Milk citrate } & 0.81 & 0.05 & 0.410 & 0.964 & 0.189 \\
\hline & Mid & 0.98 & 0.86 & 0.87 & 0.86 & 0.06 & 0.291 & 0.463 & 0.367 \\
\hline & Late & 0.81 & 0.86 & 0.87 & 0.78 & 0.04 & 0.640 & 0.899 & 0.135 \\
\hline
\end{tabular}

$\overline{\mathrm{SEM}}=$ Standard Error of the Mean; ${ }^{1} \mathrm{p}$-values for the effects; MFC = Misty-Fan Cooling effect; rbST = rbST effect; MFC x rbST = Interaction effect of MFC and rbST

NADPH production from glucose: The requirement of NADPH for fatty acid synthesis which was calculated from milk fatty compositions and output is shown in Table 10. The NADPH productions for fatty acid synthesis were significantly increased by supplemental rbST in each stage of lactation in both cooled and non-cooled cows. The percentage of NADPH production from glucose via the pentose phosphate pathway was considerable variation throughout stages of lactation in cooled and non-cooled cows.

The $3 \mathrm{H} / 14 \mathrm{C}$ ratio in glucose and related products: The ${ }^{3} \mathrm{H} /{ }^{14} \mathrm{C}$ ratios in plasma glucose and related products are shown in Table 11 . The ${ }^{3} \mathrm{H} /{ }^{14} \mathrm{C}$ ratio in arterial plasma glucose was lower than that of the infusion in both groups. These values were not different among cooled and non-cooled cows supplemental rbST in different stages of lactation, indicating some recycling of glucose- $\mathrm{C}$ in the whole animals during periods of study. A further decrease in the ${ }^{3} \mathrm{H} /{ }^{14} \mathrm{C}$ ratio was seen in milk lactose. As the glucose moiety of lactose arises directly from plasma glucose, this decrease in the ratio was due to metabolism of glucose 6-phosphate within the udder before incorporation into lactose as galactose. The ${ }^{3} \mathrm{H} /{ }^{14} \mathrm{C}$ ratio of milk triacylglycerol was shown to be high whether with or without rbST in both cooled and non-cooled cows, indicating ${ }^{3} \mathrm{H}$-glucose was removed and detected in milk triacylglycerol. The ${ }^{3} \mathrm{H}$ and ${ }^{14} \mathrm{C}$ from glucose were shown to be incorporated into milk citrate. The ${ }^{3} \mathrm{H} /{ }^{14} \mathrm{C}$ ratio of milk citrate was not affected by cooling or rbST supplementation.

\section{DISCUSSION}

In the present study, the values of THI in NS and MF barns in either morning or afternoon, were always higher than critical value (THI 72) for lactating dairy cows housing in both barns (Smith et al., 2006). 
Crossbred cows in the present study were therefore always subjected to moderate heat stress throughout experimental periods (i.e., THI $=78.3-85.4$ ). The effect of misters and fans cooling in the present study was not sufficient to completely eliminate heat stress in cows because THI measured under the cooling system remained high. The THI values might not accurately reflect heat stress when using a mister and fan system for evaporative cooling that result in higher humidity but also cause cooling. Although the cooling effect using the misty-fan system was not sufficient to adequately reduce THI in the barn, but there is a beneficial effect as indicated by a lower RR and RT in cooled cows and also higher milk yield throughout lactation. These results support the study of Fike et al. (2002) that housing cows during the day with fans and sprinklers effectively reduced heat stress as indicated by lower body temperature and respiration rate. In the present study in both groups, milk yield was increased by rbST which accompanied with increases in both RT and RR throughout the experimental periods. The observation for an increase in heat production during rbST supplementation agrees with the reports of West et al. (1991) and West (1994) that rbST-treated cows can increase heat production in a hot environment either high or lower milk producing cows.

It is known that dairy cattle adapt to high temperatures with variety of hormonal and metabolic responses, which may involve changes in the process of milk synthesis in the mammary gland. Milk yield initially showed significant increases in early lactation of cooled and non-cooled cows either supplemental rbST or not and it decreased as lactation advances. These findings confirm that an increase in milk yield in response to rbST administration will not be sustained indefinitely (Bauman, 1992) and it is influenced by the stage of lactation (Phipps et al., 1991). The low potential for extended persistency of lactation in rbST treated cows appears similar to that which occurs in higher yielding cows (Chase, 1993). However, it has been reported that the response to bovine somatotropin for whole lactation might be reduced if treatment begins very early in lactation (Burton et al., 1994; Bauman and Vernon, 1993). It is known that milk production requires glucose for synthesis of lactose which is essential for milk secretion and glucose moiety of lactose arises directly from plasma glucose (Ebner and Schanbacher, 1974). An increase in milk yield without an alteration of the plasma glucose concentration during supplemental rbST in both cooled and non-cooled cows indicates that a substantial increase in supply of glucose to the mammary gland would depend mainly on the capacity for transmembrane transport and/or intracellular metabolism of glucose. An increase in mammary blood flow is a factor for glucose uptake by the mammary gland (Linzell, 1973), which the rate of mammary plasma flow of cows was significantly increased by supplemental rbST. However, an increase in mammary plasma flow coinciding with the high level of endogenouse IGF-I, which was inferred during rbST supplementation (Chaiyabutr et al., 2005), or increase in circulating concentrations of IGF-I during prolonged exposure to a long daily photoperiod (Spicer et al., 2007), would not be a major determinant in the mediation of nutrient delivery and uptake by the mammary gland for increase in milk production throughout lactation. Local changes for biosynthetic capacity within the mammary gland would be a factor in identification of the utilization of substrates in the rate of decline in milk yield with advancing lactation (Chaiyabutr et al., 2005).

Effects of supplemental $\mathrm{rbST}$ and cooling on glucose kinetics are shown in Table 5 and 6 . The maintenance of the plasma glucose concentrations over a wide range at different stages of lactation in both cooled and non-cooled cows indicates that steady state conditions between the rate of gluconeogenesis and the rate of utilization of glucose existed in the body pool of glucose in both groups. However, it has been reported that the plasma glucose concentration would increase during injection of bovine somatotropin in cows with low milk yield but not in cows with high milk yields (Bines et al., 1980). The reversible turnover rate of [3$\left.{ }^{3} \mathrm{H}\right]$ glucose (the total glucose entry rate) and the irreversible turnover rate of $\left[\mathrm{U}-{ }^{14} \mathrm{C}\right]$ glucose (the utilization rate of glucose) of cooled cows without rbST were slightly higher than those of non-cooled cows in all stages of lactation. It is probably that the turnover rate of glucose correlated positively with a higher milk yield in cool cows. However, both glucose entry and utilization rates were not affected by supplementation of rbST in both cooled and non-cooled cows throughout lactation. It is possible that both cooled and non-cooled cows with or without supplemental rbST were fed TMR diet to satisfy requirements for metabolizable energy and the body weights increased stepwise throughout periods of study. It indicates that both cooled and noncooled cows were in positive energy balance. These findings would not affect the irreversible loss of glucose, which has been shown to increase in cows with negative energy balance (McDowell et al., 1987). The reversible turnover rate of $\left[3-{ }^{3} \mathrm{H}\right]$ glucose represents the total glucose turnover rate as the ${ }^{3} \mathrm{H}$ is not recycled from products of partial glucose degradation (Katz et al., 1965). Thus, recycling of glucose-C was estimated by simultaneous infusion of $\left[3-{ }^{3} \mathrm{H}\right]$ glucose 
and $\left[\mathrm{U}_{-}{ }^{14} \mathrm{C}\right]$ glucose in both cooled and non-cooled cows, which was not affected by rbST in each stage of lactation. These findings suggest that a constant level of tricarbon units originally derived from glucose being again reincorporated into glucose.

The utilization of glucose across the mammary gland during supplemental rbST in both cooled and non-cooled cows at different stages of lactation are complex regulatory mechanisms. It would depend both on the partitioning of blood flow between extramammary tissues and local regulation. The present results for the mammary uptake of plasma glucose in both groups were not based on changes in A-V concentration differences and extraction ratio of glucose. An increase in the rate of blood flow to the mammary gland during supplemental rbST in both cooled and non-cooled cows would be a major determinant of the rate of glucose uptake by the mammary gland. In all stages of lactation, the net mammary glucose uptake were increased approximately $8-48 \%$ by supplemental rbST in both cooled and non-cooled cows. Glucose extracted by the mammary gland has several possible metabolic fates in mammary epithelial cells that may occur at another level than transmembrane transport (Xiao and Cant, 2003). The glucose uptake by the mammary gland during supplemental rbST and cooling would be rate limiting for the transport of glucose to the mammary cell. The high blood flow to the mammary gland during supplemental rbST would decrease the transit time of glucose, thereby reduction for prolonging the contact time between glucose in blood and glucose transporter in mammary epithelial cell (Chaiyabutr et al., 2007).

It is known that glucose is an important intermediary of metabolism for the biosynthesis of lactose, triacylglycerol and citrate by the mammary gland. The bovine mammary gland cannot synthesize its own glucose because of lacking of glucose-6phosphatase (Scott et al., 1976). Glucose plays a crucial role in their metabolism and lactose synthesis, which is formed in Golgi vesicles from a combination of glucose either directly or after phosphorylation to glucose 6phosphate and conversion to UDP-galactose (Ebner and Schanbacher, 1974). The calculated amount of metabolism of glucose 6-phosphate to the galactose moiety of lactose during supplemental rbST in both cooled and non-cooled cows in each stage of lactation would be sufficient to account for the cytosolic lactose synthesis. The utilization of glucose carbon incorporation to lactose in the udder were increased by supplemental rbST in early and mid lactation but not for late lactation in both cooled and non-cooled cows (Table 7). The decrease in the metabolism of glucose 6- phosphate to the galactose moiety of lactose as lactation advanced to late lactation in both cooled and noncooled cows would affect to the lactose synthesis and milk production. A low enzymatic activity for lactose synthesis might be expected to appear as lactation advances. According to Davis and Bauman (1974), 50$60 \%$ of the glucose in the glucose-6-phosphate pool is converted into galactose. Major part of the galactose has been shown to derive from mammary extracted glucose, as well as from glycerol and other metabolic pathways. However, glucose is not the sole carbon source for lactose synthesis but remains the main one. An increase in the glucose concentration in milk representing an increase in glucose concentration in the mammary epithelial cell during prolonged treatment of rbST has been noted (Chaiyabutr et al., 2008c).

It is known that $80-85 \%$ of lactose carbon atoms arise from glucose (Faulkner and Peaker, 1987). The quantitative utilization of the glucose taken up by the mammary gland is used directly in the synthesis of lactose, while the remaining of extracted glucose can participate in the supply of ATP (Embden-Meyerhof pathway and the tricarboxylic acid cycle), other portions would be metabolized via the pentose phosphate pathway, In the present studies, glucose 6phosphate was metabolized via the pentose phosphate pathway by average 11.0-16.5\% in both cooled and non-cooled cows without rbST, while it was increased by supplemental rbST from $13.2-16.8 \%$ in early and mid-lactation but these values were decreased in the late lactation (Table 8). These results agree with prolonged treatment of rbST in crossbred HF cows, which percentage of glucose 6-phosphate metabolized via the pentose phosphate pathway were variable in different stages of lactation (Chaiyabutr et al., 2008b). However, these findings differed to those studies in the isolated perfused udder of cow by Wood et al. (1965), in which about 23-30\% of the glucose was metabolized via the pentose phosphate pathway. It is probable that no consideration of the recycling of glucose 6phosphate metabolized via the pentose cycle in the udder with the consequent loss of ${ }^{3} \mathrm{H}$ from glucose 6phosphate (Davis and Bauman, 1974). However, the net proportion of the metabolism of glucose 6-phosphate via the pentose cycle pathway was increased by supplemental rbST at early stage of lactation of cooled and non-cooled cows. Metabolism of glucose via the pentose phosphate pathway yields 2 molecules of NADPH per molecule of glucose, only one of which could be labelled with ${ }^{3} \mathrm{H}$ in the present experiments. In the present studies, estimation of the contribution of the pentose phosphate pathway in providing NADPH for fatty acid synthesis in vivo have been estimated by 
based on the assumption that all the glucose that was oxidized to $\mathrm{CO}_{2}$, which was metabolized via the pentose phosphate pathway. High metabolism of glucose 6-phosphate in early and mid lactation of rbST treated cows appeared to be due primarily to a high flux through the lactose synthesis and to pentose phosphate pathway, probably reflecting the high milk production during rbST supplementation.

The utilization of glucose carbon by the mammary epithelial cell for the synthesis of milk compositions of lactose, citrate and triacylglycerol (Table 7) show that absolute amount of glucose carbon incorporation to milk lactose were increased by supplemental rbST in early and mid lactation in both cooled and non-cooled cows but it decreased in late lactation. These findings would parallel to its effects on milk yield. It indicates that during supplemental rbST in late lactation, the metabolism of glucose-6-phosphate declines the flux towards the pentose phosphate pathway and in lactose synthesis. In parallel, a higher proportion of glucose-6phosphate would be metabolized via the EmbdenMeyerhof pathway and was oxidized in the tricarboxylic acid cycle.

Both the proportion and absolute amount of glucose carbon incorporation to milk triacylglycerol were increased, while glucose carbon incorporation to milk citrate was slightly decreased by supplemental rbST. It is known that, citrate would not be used directly as a carbon source for lipogenesis in ruminant; it does appear to be directly involved in the provision of reducing equivalent (NADPH). These changes can be interpreted in terms of metabolic shifts occurring within the mammary epithelial cell. It might speculate that such changes reflect more flux of the utilization of glucose carbon by the mammary epithelial cell through the synthesis of lactose and milk triacylglycerol during supplemental rbST. In addition to the use of glucose carbon for milk triacylglycerol synthesis, the hydrogen from glucose has shown to be incorporated more into milk fatty acid in early and mid lactation in both cooled and non-cooled cows supplemental rbST (Table 8), although studies in vitro have shown that fatty acid synthesis could occur from the utilization of acetate in the perfused goat udder (Hardwick et al., 1963). It has been known that milk fat is synthesized from fatty acids of both blood lipids and from de novo synthesis within the mammary epithelial cells. However, an increase in milk fat concentration after rbST supplementation was associated with the increased yield of long-chain fatty acids characteristic of plasma free fatty acids and body fat. Significant increases in plasma free fatty acids in rbST-treated cows have been published elsewhere (Chaiyabutr et al., 2007). Thus, the lipolytic activity would be a function of rbST treatment per se instead of the associated changes in energy balance.

Glucose can also participate in the milk fat formation, by supplying the glycerol (triose phosphate pathway) and the NADPH essential to elongating milk fatty acids (pentose phosphate and isocitrate dehydrogenase pathways). However, very marginally, less than $11 \%$ of glucose could supply carbon atoms for the synthesis of milk triacylglycerol in either supplemental rbST or cooling. The method used to estimate NADPH requirement for fatty acids synthesis in the present study is calculated from the incorporation of ${ }^{3} \mathrm{H}$ from $\left[3-{ }^{3} \mathrm{H}\right]$ glucose in fatty acids, which assume that the NADPH is used exclusively for biosynthesis of fatty acids (Katz et al., 1974). This technique has been used to study the in vitro metabolism of rat mammary and adipose tissue (Katz and Wals, 1970; Katz and Wals, 1972; Katz et al., 1966) and it has also been used for the study of the in vivo metabolism of goat mammary tissue (Chaiyabutr et al., 1980). Data from the present study (Table 10) provide evidences that the requirement of NADPH for fatty acid synthesis de novo in the udder were ranging $16.7-35.4 \%$ in cooled and non-cooled cows without rbST and 17.8-26.5\% during rbST supplementation. If there is a common pool of glucose 6-phosphate which is available for both lactose synthesis and pentose phosphate metabolism; then the recycling of glucose 6-phosphate within the udder could show a low value for NADPH production from glucose metabolism in the present results.

Metabolism of glucose 6-phosphate via the pentose phosphate pathway usually loss of all ${ }^{3} \mathrm{H}$ from $\left[3-{ }^{3} \mathrm{H}\right]$ glucose in lactating cows. During lactation, a higher level of ${ }^{3} \mathrm{H} /{ }^{14} \mathrm{C}$ ratio in milk triacyglycerol (Table 11) would be due to an increase in disequilibrium of the triose phosphate isomerase reaction occurring in the udder of crossbred animals, which needs to be further investigated. Tritium and carbon-14 in glucose molecule were also shown to be incorporated into milk citrate which provided by averaged $22 \mu \mathrm{mol} \mathrm{min} \mathrm{m}^{-1}$ (16.5-0.25.5) in cooled and non-cooled cows without

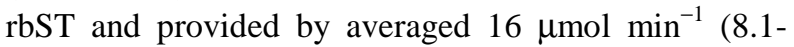
21.2) for the carbon skeleton of citrate during rbST supplementation in both groups. Milk citrate could be synthesized from 2-oxoglutarate via the NADPdependent isocitrate dehydrogenase reaction (Hardwick, 1965). In addition ${ }^{3} \mathrm{H}$ is lost to NADPH or water in metabolism via the pentose phosphate pathway or glycolytic pathway, so it is likely that ${ }^{3} \mathrm{H}$ incorporation into milk citrate was also via $\mathrm{NADP}^{3} \mathrm{H}$. It is possible that the incorporation of ${ }^{3} \mathrm{H}$ into milk citrate may occur in different manners in the exchange reaction of the cytosolic NADP-dependent isocitrate 
dehydrogenase. Both fatty acid synthesis and the NADP-dependent isocitrate dehydrogenase reaction may have different mechanisms with a common pool of cytosolic NADPH between cows without rbST and cows supplemental rbST. The concentrations of FFA in milk were significantly increased by supplemental rbST in cooled and non-cooled cows (Table 7). A similar result for an increase in milk fat content due to prolonged administration of rbST has also been observed previously (West et al., 1991; Chaiyabutr et al., 2000b). It has been known that milk fat is synthesized from fatty acids of both blood lipids and from de novo synthesis within the mammary epithelial cells.

\section{CONCLUSION}

The data presented here represent the estimation in vivo of glucose metabolism in the mammary gland and its distribution to lactose synthesis, the pentose phosphate pathway and the Embden-Meyerhof pathway by the effects of supplemental rbST and cooling in $87.5 \% \mathrm{HF}$ animals. The rbST exerts its galactopoietic action, in part, association with an increase in mammary blood flow, which partitions the distribution of glucose to the mammary gland. The stimulant effect for milk yield by supplemental rbST was transiently and the glucose turnover rate was not significantly increased as compared with pre-treatment period in all stages of lactation. It indicates that $\mathrm{rbST}$ induced enhancement of milk yield in all stages of lactation, which would be compensated by mobilization of body energy reserves (i.e. plasma free fatty acids) to the extent of the elevated energy requirements for supporting the increased milk production. In early and mid lactation, the glucose taken up by the udder of both cooled and non-cooled cows with rbST and without supplemental rbST, were metabolized in the pentose phosphate pathway and contributed to NADPH production by mean average 14 and $24 \%$, respectively. An increased flux of the sufficient pool of intracellular glucose 6-phosphate during early and mid lactation came across through the lactose synthesis and pentose cycle pathway. On late lactation of both cooled and non-cooled cows, the reductions of the metabolism of glucose taken up by the udder via the pentose phosphate pathway and the contribution to NADPH production were apparent by mean averaged $9 \%$ and $22 \%$, respectively. It would appear that a larger proportion of the glucose 6-phosphate was metabolized via Embden-Meyerhof pathway in late lactation. The present results suggest that the regulation of biosynthetic capacity within the mammary gland would be influenced more by local than by systemic factors in identification of the utilization of substrates in the rate of decline in milk yield with advanced lactation.

\section{ACKNOWLEDGEMENT}

This study was partly supported by The Thailand Research Fund (grant\# BRG498004) S. Sitprija is the recipient a grant from Faculty of Science, Mahidol University, Thailand. The authors have no confliction of interest to declare.

\section{REFERENCES}

Annison, E.F. and J.L. Linzell, 1964. The oxidation and utilization of glucose and acetate by the mammary gland of the goat in relation to their overall metabolism and milk formation. J. Physiol., 175: 372-385. PMCID: PMC1357142

Bauman, D.E. and R.G. Vernon, 1993. Effects of bovine somatotropin on lactation. Annu. Rev. Nutr., 13: 437-461. PMID: 8369154

Bauman, D.E. and W.B. Currie, 1980. Partitioning of nutrients during pregnancy and lactation: A review of mechanisms involving homeostasis and homeorhesis. J. of Dairy Sci., 63: 1514-1529. PMID: 7000867

Bauman, D.E., 1992. Bovine somatotropin: Review of an emerging animal technology. J. Dairy Sci., 75: 3432-3451. PMID: 1474210

Bickerstaffe, R., E.F. Annison and J.L. Linzell, 1974. The metabolism of glucose, acetate, lipids and amino acids in lactating dairy cows. J. Agric. Sci. (Camb)., 82: 71-85. DOI: 10.1017/S0021859600050243

Bines, J.A., I.C. Hart and S.V. Morant, 1980. Endocrine control of energy metabolism in the cow: The effect on milk yield and levels of some blood constituents of injecting growth hormone and growth hormone fragments. Brit. J. Nutr., 43: 179-188. PMID: 6989393

Breier, B.H., P.D. Gluckman, S.N. McCutcheon and S.R. Davis, 1991. Physiological responses to somatotropin in the ruminant. J. Dairy Sci., 74: 20-34. PMID: 1795061

Burton, J.L., B.W. McBride, E. Block, D.R. Glimm and J.J. Kennelly, 1994. A review of bovine growth hormone. Can. J. Anim. Sci., 74: 167-201.

Chaiyabutr, N. and C. Buranakarl, 1989. Effects of exogenous urea infusion on glucose metabolism in acute heat stressed swamp buffaloes (Bubalus bubalis). Brit. Vet. J., 145: 538-545. DOI: 10.1016/0007-1935(89)90115-2

Chaiyabutr, N., A. Faulkner and M. Peaker, 1980. The Utilization of glucose for the synthesis of milk components in the fed and starved lactating goat in vivo. Biochem. J., 186: 301-308. PMCID: PMC1161531 
Chaiyabutr, N., S. Chanpongsang and S. Suadsong, 2008a. Effects of evaporative cooling on the regulation of body water and milk production in crossbred Holstein cattle in a tropical environment. Int. J. Biometeorol., 52: 575-585. DOI: 10.1007/s00484-008-0151-X

Chaiyabutr, N., S. Thammacharoen, S. Komolvanich and S. Chanpongsang, 2008b. Effects of long-term exogenous bovine somatotropin on glucose metabolism and the utilization of glucose by the mammary gland in different stages of lactation of crossbred Holstein cattle. Anim. Sci. J., 79: 561-574. DOI: $10.1111 /$ j.1740-0929.2008.00565.X

Chaiyabutr, N., S. Thammacharoen, S. Komolvanich and S. Chanpongsang, 2008c. Effects of long-term administration of recombinant bovine somatotropin on the concentration of metabolites in milk in different stages of lactation in Crossbred Holstein cattle. Anim. Sci. J., 79: 41-50. DOI: 10.1111/j.1740-0929.2007.00496.x

Chaiyabutr, N., S. Preuksagorn, S. Komolvanich and S. Chanpongsang, 2000a. Comparative study on the regulation of body fluids and mammary circulation at different states of lactation in crossbred Holstein cattle feeding on different types of roughage. J. Anim. Physiol. Anim. Nutr., 83: 74-84. DOI: 10.1046/j.14390396.2000.00251.x

Chaiyabutr, N., S. Komolvanich, S. Preuksagorn, S. Chanpongsang, 2000b. Comparative studies on the utilization of glucose in the mammary gland of crossbred Holstein cattle feeding on different types of roughage during different stages of lactation. Asian Aus. J. Anim., 13: 334-347.

Chaiyabutr, N., S. Komolvanich, S. Sawangkoon, S. Preuksagorn and S. Chanpongsang, 1998. Glucose metabolism in vivo in crossbred Holstein cattle feeding on different types of roughage during late pregnancy and early lactation. Com. Biochem. Physiol., Part A., 119: 905-913. DOI: 10.1016/S1095-6433(98)00002-6

Chaiyabutr, N., S. Komolvanich, S. Sawangkoon, S. Preuksagorn and S. Chanpongsang, 1997. Regulation of body fluids and mammary circulation during late pregnancy and early lactation of crossbred Holstein cattle feeding on different types of roughage. J. Anim. Physiol. Nutr., 77: 167-179.

Chaiyabutr, N., S. Thammacharoen, S. Komolvanich and S. Chanpongsang, 2007. Effects of long term exogenous bovine somatotropin on nutrients uptake by the mammary glands of crossbred Holstein cattle in the tropics. Asian-Aust. J. Anim. Sci., 20: 1407-1416.
Chaiyabutr, N., S. Thammacharoen, S. Komolvanich and S. Chanpongsang, 2005. Effects of long-term administration of recombinant bovine somatotropin on milk production and plasma insulin-like growth factor and insulin in Crossbred Holstein Cows. J. Agric. Sci. (Camb), 143: 311-318. DOI: 10.1017/S0021859605005538

Chan, S.C., J.T. Hubber, K.H. Chen, J.M. Simas and Z. Wu, 1997. Effects of ruminally inert fat and evaporative cooling on dairy cows in hot environmental temperatures. J. Dairy Sci., 80: 1172-1178. PMID: 9201588

Chase, L.E., 1993. Developing nutrition programs for high producing dairy herds. J. Dairy Sci., 76: 3287-3293. PMID: 8227648

Christopherson, S.W. and R.L. Glass, 1969. Preparation of milk fat methyl esters by alcoholysis in an essentially nonalcoholic solution. J. Dairy Sci., 52: $\quad 1289-1290 . \quad$ DOI: $10.3168 /$ jds.S00220302(69)86739-1

Collier, R.J., D.K. Beede, W.W. Thatcher, L.A. Israel and C.J. Wilcox, 1982. Influences of environment and its modification on dairy animal health and production. J. Dairy Sci., 65: 2213-2227. PMID: 6759540

Davis, C.L. and D.E. Bauman, 1974. General Metabolism Associated with the Synthesis of Milk. In: Lactation, Larson, B.L. and V.R. Smith (Eds.). Academic Press, New York, London, pp: 3-30.

Dole, V.P., 1956. A relation between non-esterified fatty acids in plasma and the metabolism of glucose. J. Clin. Invest., 35: 150-154. DOI: 10.1172/JCI103259

Ebner, K.E. and F.L. Schanbacher, 1974. Biochemistry of Lactose and Related Carbohydrates. In: Lactation, Larson, B.L. and V.R. Smith (Eds.). Academic Press, New York, London, pp: 77-113.

Emery, R.S., L.D. Brown and J.W. Bell, 1965. Correlation of milk fat with dietary and metabolic factor in cows fed restricted-roughage ration supplemented with magnesium oxide or sodium bicarbonate. J. Dairy Sci., 48, 1647-1651. DOI: 10.3168/JDS.S0022-0302(65)88543-5

Faulkner, A. and M. Peaker, 1987. Regulation of Mammary Glucose Metabolism in Lactation. In: The Mammary Gland: Development, Regulation and Function, Neville, M.C. and C.W. Daniel (Eds.). Plenum Press, New York, pp: 535-562.

Fike, J.H., C.R. Staples, L.E. Sollenberger, J.E. Moore and H.H. Head, 2002. Southeastern pasture based dairy systems: Housing, posilac and supplemental silage effects on cow performance. J. Dairy Sci., 85: 866-878. PMID: 12018432 
Hardwick, D.C., 1965. The incorporation of carbondioxide into milk citrate in the isolated perfused goat udder. Biochem. J., 95: 233-237. PMCID: PMC1215198

Hardwick, D.C., J.L. Linzell and T.M. Mepham, 1963. The metabolism of acetate and glucose by the isolated perfused udder. 2. The contribution of acetate and glucose to carbon dioxide and milk constituents. Biochem. J., 88: 213-220. PMCID: PMC1202099

Katz, J. and P.A. Wals, 1970. Effect of phenazine methosulfate on lipogenesis. J. Biol. Chem., 245: 2546-2548. PMID: 4315646

Katz, J. and P.A. Wals, 1972. Pentose cycle and reducing equivalents in rat mammary gland slices. Biochem. J., 128: 879-899. PMID: 4404768

Katz, J. and Wood H.G., 1963. The use of $\mathrm{C}^{14} \mathrm{O}_{2}$ yields from glucose-1-and $6-\mathrm{C}^{14}$ for the evaluation of the pathways of glucose metabolism. J. Biol. Chem., 238: 517-523. PMID: 13958489

Katz, J., B.R. Landau and G.E. Bartsch, 1966. The pentose cycle, triosephosphate isomerization and lipogenesis in rat adipose tissue. J. Biol. Chem., 241: 727-740. PMID: 4379536

Katz, J., P.A. Wals, R.L and van de Velde, 1974. Lipogenesis by acini from mammary gland of lactating rats. J. Biol. Chem., 249: 7348-7357. PMID: 4373465

Katz, J., R. Rognstad and R.G. Kemp, 1965. Isotope discrimination effects in the metabolism of tritiated glucose. J. Biol. Chem., 240: 1484-1486.

Kirchgessner, M., W. Windisch, W. Schwab and H.L. Muller, 1991. Energy metabolism of lactating dairy cows treated with prolonged-release bovine somatotropin or energy deficiency. J. Dairy Sci., 74: 35-43. PMID: 1795062

Linzell, J.L. and M. Peaker, 1971. Mechanisms of milk secretion. Physiol. Rev., 51: 564-597.

Linzell, J.L., 1973. The Demands of the Udder and Adaptation to Lactation. In: Production Disease in Farm Animals, Payne, J.M., K.G. Hibbitt and B.F. Sansom (Eds.). Bailliere, Tindal, London, pp: 89-160.

McDowell, G.H., J.M. Gooden, D. Leenanuruksa, M. Jois and A.W. English, 1987. Effects of exogenous growth hormone on milk production and nutrient uptake by muscle and mammary tissue of dairy cows in mid-lactation. Aust. J. Biol. Sci., 40: 295-306. PMID: 3327491

Phipps, R., C. Madakadze, T. Mutsvangwa, D.L. Hard and G.D. Kerchove, 1991. Use of bovine somatotropin in the tropics: the effect of sometribove on milk production of Bos indicus, dairy crossbred and Bos taurus cows in Zimbabwe. J. Agric. Sci. (Camb), 117: 257-263. DOI: $10.1017 /$ S0021859600065369
Scott, R.A., D.E. Bauman and J.H. Clark, 1976. Cellular gluconeogenesis by lactating bovine mammary tissue. J. Dairy Sci., 59: 50-56. PMID: 175103

Smith, T.R., A. Chapa, S. Willard, C. Herndon Jr and R.J. Williams et al., 2006. Evaporative tunnel cooling of dairy cows in the southeast. II impact on lactation performance. J. Dairy Sci., 89: 3915-3923. PMID: 16960067

Spicer, L.J., B.A. Buchanan, L.T. Chapin and H.A. Tucker, 2007. Effect of exposure to various durations of light on serum insulin-like growth factor-I in prepubertal holstein heifers. Am. J. Anim. Vet. Sci., 2: 42-45. DOI: 10.3844/ajavsp.2007.42.45

Teles, F.F.F., C.K. Young and J.W. Stull, 1978. A method for rapid determination of lactose. J. Dairy Sci., 61: 506-508. DOI: 10.3168/JDS.S00220302(78)83626-1

Thompson, G.E. and E.M. Thomson, 1977. Effect of cold exposure on mammary circulation, oxygen consumption and milk secretion in the goat. J. Physiol, 272: 187-196. PMID: 563444

Wang, A.S., D.F. Jan, K.J. Chen, D.W. Yang and Y.K. Fan, 2004. Dietary supplementation of increased milk fat percentage without affecting ruminal characteristics in Holstein cows in a warm tropical environment. Asian. Aust. J. Anim., 17: 213-220.

West, J.W., 1994. Interactions of energy and bovine somatotropin with heat stress. J. Dairy Sci., 71: 2091-2102. PMID: 7929967

West, J.W., B.G. Mullinix and T.G. Sandifer, 1991. Effects of bovine somatotropin on physiologic responses of lactating Holstein and Jersey cows during hot, humid weather. J. Dairy Sci., 74: 840-851. PMID: 1906487

White, J.C.D. and D.T. Davies, 1963. The determination of citric acid in milk and milk sera. J. Dairy Res., 30: 171-189. DOI: 10.1017/S0022029900011353

Wood, H.G., G.J. Peeters, R. Verbeke, M. Lauryssens and B. Jacobson, 1965. Estimation of the pentose cycle in the perfused cow's udder. Biochem. J., 96: 607-615. PMID: 5862402

Xiao, C. and J.P. Cant, 2003. Glucose transporter in bovine mammary epithelial cells is an asymmetric carrier that exhibits cooperativity and transstimulation. Am. J. Physiol. Cell Physiol., 285: C1226-C1234. PMID: 12867359

Yang, W.R., H. Sun, Q.Y. Wang, F.X. Liu and Z.B. Yang, 2010. Effects of rumen-protected methionine on dairy performance and amino acid metabolism in lactating cows. Am. J. Anim. Vet. Sci., 5: 1-7. DOI: 10.3844/ajavsp.2010.1.7 